\title{
Development of novel positron emitters for medical applications: nuclear and radiochemical aspects
}

\author{
By S. M. Qaim* \\ Institut für Neurowissenschaften und Medizin, INM-5: Nuklearchemie, Forschungszentrum Jülich GmbH, 52425 Jülich, Germany
}

(Received December 15, 2010; accepted in revised form May 12, 2011)

\author{
Novel positron emitter / Nuclear data / \\ Low and intermediate energy reactions / Targetry / \\ Radiochemical separation / Production yield / \\ Quality control / Radionuclide generator / \\ New generation high power accelerator
}

\begin{abstract}
Summary. In molecular imaging, the importance of novel longer lived positron emitters, also termed as non-standard or innovative PET radionuclides, has been constantly increasing, especially because they allow studies on slow metabolic processes and in some cases furnish the possibility of quantification of radiation dose in internal radiotherapy. Considerable efforts have been invested worldwide and about 25 positron emitters have been developed. Those efforts relate to interdisciplinary studies dealing with basic nuclear data, high current charged particle irradiation, efficient radiochemical separation and quality control of the desired radionuclide, and recovery of the enriched target material for reuse. In this review all those aspects are briefly discussed, with particular reference to three radionuclides, namely ${ }^{64} \mathrm{Cu},{ }^{124} \mathrm{I}$ and ${ }^{86} \mathrm{Y}$, which are presently in great demand. For each radionuclide several nuclear routes were investigated but the $(p, n)$ reaction on an enriched target isotope was found to be the best for use at a small-sized cyclotron. Some other positron emitting radionuclides, such as ${ }^{55} \mathrm{Co},{ }^{76} \mathrm{Br},{ }^{89} \mathrm{Zr},{ }^{82 \mathrm{~m}} \mathrm{Rb},{ }^{94 \mathrm{~m}} \mathrm{Tc},{ }^{120} \mathrm{I}$, etc., were also produced via the low-energy $(p, n),(p, \alpha)$ or $(d, n)$ reaction. On the other hand, the production of radionuclides ${ }^{52} \mathrm{Fe},{ }^{73} \mathrm{Se},{ }^{83} \mathrm{Sr}$, etc. using intermediate energy $(p, x n)$ or $(d, x n)$ reactions needs special consideration, the nuclear data and chemical processing methods being of key importance. In a few special cases, a high intensity ${ }^{3} \mathrm{He}$ - or $\alpha$-particle beam could be an added advantage. The production of some potentially interesting positron emitters via generator systems, for example ${ }^{44} \mathrm{Ti} /{ }^{44} \mathrm{Sc},{ }^{72} \mathrm{Se} /{ }^{72} \mathrm{As}$ and ${ }^{140} \mathrm{Nd} /{ }^{140} \mathrm{Pr}$ is considered. The significance of new generation high power accelerators is briefly discussed.
\end{abstract}

\section{Introduction}

Radionuclides find application in many fields. However, their major use is in medicine, both for diagnosis and therapy [cf. 1]. This is manifested by the International Symposium on Radiopharmaceutical Sciences, held biennially in some part of the world. The underlying principle of an

\footnotetext{
*E-mail: s.m.qaim@fz-juelich.de.
}

in vivo diagnostic application is that the radiation dose to the patient is as low as possible, compatible with the desired quality of imaging. This calls upon the use of very special radionuclides which can be detected efficiently from outside of the body. In general, short-lived $\gamma$-ray emitters or positron emitters are commonly used, the former finding application in Single Photon Emission Computed Tomography (SPECT) and the latter in Positron Emission Tomography (PET). In contrast, an internal therapeutic application requires that a certain amount of dose is specifically deposited in a malignant tissue. Thus for internal radiotherapy, radionuclides emitting corpuscular radiation ( $\alpha$ - or $\beta^{-}$particles, conversion and/or Auger electrons) are of interest.

The production of radionuclides for medical applications is carried out using both nuclear reactors and cyclotrons. The most commonly used SPECT radionuclide ${ }^{99 \mathrm{~m}} \mathrm{Tc}\left(T_{1 / 2}=6.0 \mathrm{~h}\right)$ is produced using a nuclear reactor. Its widespread use is mainly based on its convenient availability as a ${ }^{99} \mathrm{Mo} /{ }^{99 \mathrm{~m}} \mathrm{Tc}$ generator. Many of the cyclotron produced $\gamma$-ray emitting radionuclides, such as ${ }^{67} \mathrm{Ga}\left(T_{1 / 2}=\right.$ $78.3 \mathrm{~h}),{ }^{111} \mathrm{In}\left(T_{1 / 2}=2.9 \mathrm{~d}\right),{ }^{123} \mathrm{I}\left(T_{1 / 2}=13.2 \mathrm{~h}\right)$ and ${ }^{201} \mathrm{Tl}$ $\left(T_{1 / 2}=73.1 \mathrm{~h}\right)$ also find application. They are commercially available. In recent years, however, the positron emitting radionuclides have been gaining more significance because PET has made it possible to quantitatively measure regional activities of a molecule (labelled with a positron emitter) with high sensitivity and a spatial resolution of a few $\mathrm{mm}$. The commonly used short-lived organic positron emitters, viz. ${ }^{11} \mathrm{C}\left(T_{1 / 2}=20.3 \mathrm{~min}\right),{ }^{13} \mathrm{~N}\left(T_{1 / 2}=10.0 \mathrm{~min}\right),{ }^{15} \mathrm{O}\left(T_{1 / 2}=\right.$ $2.0 \mathrm{~min})$ and ${ }^{18} \mathrm{~F}\left(T_{1 / 2}=110 \mathrm{~min}\right)$, are produced via lowenergy nuclear reactions at small-sized cyclotrons [cf. 2]. Besides those four organic positron emitters, two other short-lived positron emitters, namely ${ }^{68} \mathrm{Ga}\left(T_{1 / 2}=67.6 \mathrm{~min}\right)$ and ${ }^{82} \mathrm{Rb}\left(T_{1 / 2}=1.3 \mathrm{~min}\right)$, are produced via generator systems. Their respective long-lived parents ${ }^{68} \mathrm{Ge}\left(T_{1 / 2}=271 \mathrm{~d}\right)$ and ${ }^{82} \mathrm{Sr}\left(T_{1 / 2}=25.3 \mathrm{~d}\right)$ are produced through intermediate energy nuclear reactions. The whole PET technology (consisting of cyclotron, radionuclide production unit, and automated radiosynthesis apparatus) is now commercially available.

Among the therapeutic radionuclides, ${ }^{131} \mathrm{I}\left(T_{1 / 2}=8.02 \mathrm{~d}\right)$ is by far the most important, having an established place in the management of follicular thyroid carcinoma. The other radioiodine, ${ }^{125} \mathrm{I}\left(T_{1 / 2}=59.41 \mathrm{~d}\right)$, is used in Auger electron therapy. Several other reactor produced radionuclides, 
for example ${ }^{32} \mathrm{P}\left(T_{1 / 2}=14.3 \mathrm{~d}\right),{ }^{89} \mathrm{Sr}\left(T_{1 / 2}=50.5 \mathrm{~d}\right),{ }^{90} \mathrm{Y}$ $\left(T_{1 / 2}=2.7 \mathrm{~d}\right)$ and ${ }^{153} \mathrm{Sm}\left(T_{1 / 2}=1.9 \mathrm{~d}\right)$, find application in palliative treatment. In recent years cyclotrons have also been increasingly used to produce some therapeutic radionuclides, in particular those emitting low energy but highly ionising radiation $[c f .3]$.

Today, research work on radionuclides for nuclear medicine is carried out mainly in two directions:

1. Development of novel longer lived positron emitters.

2. Development of novel low-energy but highly ionising radiation emitters for internal radiotherapy.

This article deals with nuclear and radiochemical aspects of development of novel positron emitters. Those radionuclides can only be produced at cyclotrons (or accelerators). With the increasing significance of PET in diagnostic nuclear medicine, the need for longer lived novel positron emitters, also termed as non-standard or innovative positron emitters, has been increasing, especially for studying slow metabolic processes [cf. 4]. Some aspects of their production have been considered [cf. 5-8]. The present review discusses their production methodologies in more detail.

\section{Fundamental considerations in development of novel positron emitters}

The development of a novel positron emitter has to comply with certain constraints with respect to production possibilities (e.g. type of available cyclotron, yield of nuclear reaction to be used, enrichment of the target material, etc.). It calls upon interdisciplinary work comprising nuclear data measurement, high-current targetry, chemical processing, automation of the procedure and quality control of the product. Furthermore, its suitability for imaging, which is related to its decay characteristics, also needs to be demonstrated. A discussion of all those aspects, is given below, furnishing examples from a few recent investigations.

\subsection{Nuclear data}

\subsubsection{Reaction cross section data}

In cyclotron production of radionuclides, the reaction cross section data play a very important role $[c f .9,10]$. One needs the full excitation function of the nuclear process under consideration to be able to calculate the expected production yield with a reasonable accuracy. The data are needed mainly for the optimization of the production route, i.e. to maximize the yield of the desired product and to minimize the yields of the radioactive impurities. The calculated yield value of the desired product represents the maximum yield which can be expected from a given nuclear process. It should be pointed out that, whereas the non-isotopic impurities produced can be removed by chemical separations, the level of isotopic impurities can be suppressed only by using an enriched isotope as target material and/or by a careful selection of the particle energy range effective in the target, the latter information being derived from the respective excitation function.

Besides isotopic impurities, isomeric impurities also need to be considered. Several novel medical radionuclides have isomeric states, which are rather disturbing. A few

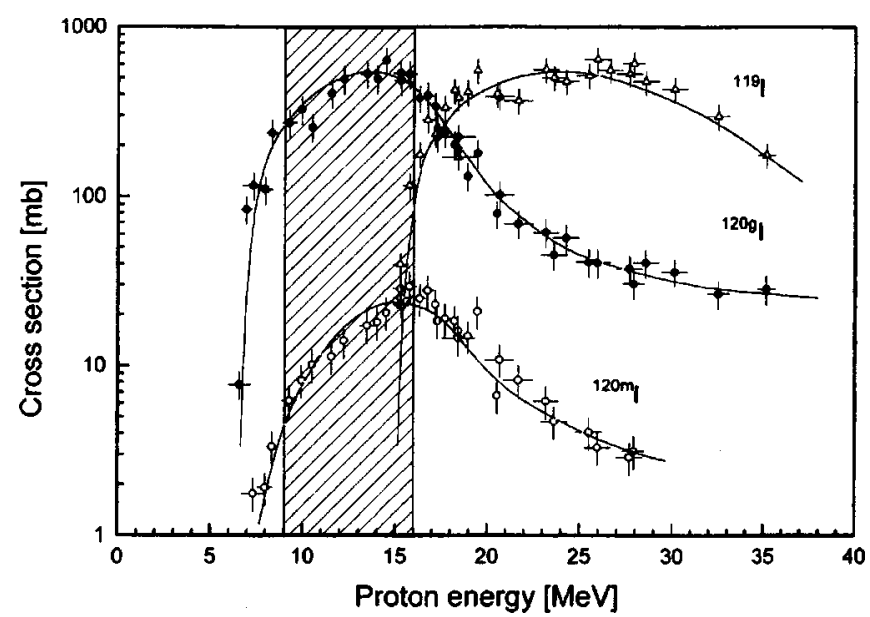

Fig. 1. Excitation functions of ${ }^{120} \mathrm{Te}(p, x n)$-reactions leading to the formation of ${ }^{120 \mathrm{~m}} \mathrm{I},{ }^{120 \mathrm{~g}} \mathrm{I}$ and ${ }^{119} \mathrm{I}$. The solid lines are eye-guides. The shaded area gives the optimum energy range for the production of ${ }^{120 g}$ I (after Ref. [13]).

examples are ${ }^{86 \mathrm{~m}} \mathrm{Y}\left({ }^{86 \mathrm{~g}} \mathrm{Y}\right),{ }^{94 \mathrm{~m}} \mathrm{Tc}\left({ }^{94 \mathrm{~g}} \mathrm{Tc}\right)$ and ${ }^{120 \mathrm{~g}} \mathrm{I}\left({ }^{120 \mathrm{~m}} \mathrm{I}\right)$. The isomeric impurities cannot be controlled through a careful adjustment of the energy window (as mentioned above). Since the isomeric cross section ratio is primarily dependent on the type of reaction involved [cf. 11], it is essential to investigate all the possible production routes and then to choose the reaction and the energy range giving the best results. Obviously, nuclear data play here a very important role. Nuclear reaction cross section measurements performed $[12,13]$ in connection with the development of the positron emitter ${ }^{120 \mathrm{~g}} \mathrm{I}\left(T_{1 / 2}=1.35 \mathrm{~h}\right)$ provide a good example of the importance of nuclear data. The results on the ${ }^{120} \mathrm{Te}(p, x n)^{119,120 \mathrm{~m}, \mathrm{~g}} \mathrm{I}$ reactions [13] are shown in Fig. 1. The energy range $E_{\mathrm{p}}=16 \rightarrow 9 \mathrm{MeV}$ appears to be optimum for the production of ${ }^{120 g} \mathrm{I}$. Over this energy range the calculated thick target yield of ${ }^{120 \mathrm{~g}} \mathrm{I}$ is high $(2.3 \mathrm{GBq} / \mu \mathrm{Ah})$, and the levels of the impurities are: ${ }^{120 \mathrm{~m}} \mathrm{I}(4.8 \%)$ and ${ }^{119} \mathrm{I}$ $(4.4 \%)$. The impurity ${ }^{119} \mathrm{I}$ is not a problem. Being short-lived $\left(T_{1 / 2}=19.1 \mathrm{~min}\right)$, it almost completely decays out during the separation of ${ }^{120 g} \mathrm{I}$ from the irradiated target. The isomeric impurity ${ }^{120 \mathrm{~m}} \mathrm{I}\left(T_{1 / 2}=53 \mathrm{~min}\right)$ is also shorter lived as compared to ${ }^{120 \mathrm{I}} \mathrm{I}$; its relative contribution would therefore decrease with the decay time. On the other hand, if the reaction ${ }^{122} \mathrm{Te}(p, 3 n)^{120 \mathrm{~m}, \mathrm{~g}} \mathrm{I}$ is used [12] for the production of ${ }^{120 \mathrm{I}} \mathrm{I}$, with a calculated thick target yield of ${ }^{120 \mathrm{I}} \mathrm{I}$ of $3.6 \mathrm{GBq} / \mu \mathrm{A}$ h over the energy range of $E_{\mathrm{p}}=37 \rightarrow 32 \mathrm{MeV}$, the contribution of ${ }^{120 \mathrm{~m}} \mathrm{I}$ may amount up to $25 \%$.

Extensive nuclear data studies in connection with the development of innovative positron emitters have been carried out at the Forschungszentrum Jülich over the last 25 years. In most of the cases the low-energy $(p, n)$ reaction on a highly enriched target isotope was found to be ideal. The pertinent examples are: ${ }^{64} \mathrm{Ni}(p, n)^{64} \mathrm{Cu}$ [14], ${ }^{76} \mathrm{Se}(p, n){ }^{76} \mathrm{Br} \quad$ [15], ${ }^{82} \mathrm{Kr}(p, n)^{82 \mathrm{~m}} \mathrm{Rb}$ [16], ${ }^{86} \mathrm{Sr}(p, n){ }^{86} \mathrm{Y}$ [17], ${ }^{94} \mathrm{Mo}(p, n)^{94 \mathrm{~m}} \mathrm{Tc} \quad$ [18], ${ }^{120} \mathrm{Te}(p, n)^{120 g} \mathrm{I} \quad$ [13] and ${ }^{124} \mathrm{Te}(p, n){ }^{124} \mathrm{I}[19]$. In the case of ${ }^{64} \mathrm{Cu},{ }^{86} \mathrm{Y}$ and ${ }^{124} \mathrm{I}$, the three most prominent novel positron emitters, the suggested $(p, n)$ reaction has become the method of choice for obtaining a high-purity product.

Besides the $(p, n)$ reaction, for several radionuclides other low and intermediate energy reactions, for example, 
$(p, \alpha),(d, n),(p, x n),(d, x n),\left({ }^{3} \mathrm{He}, x n\right)$ and $(\alpha, x n)$, have also been investigated. Furthermore, in several cases, for example ${ }^{64} \mathrm{Cu}$ and ${ }^{124} \mathrm{I}$, extensive comparisons of various production routes have been presented $[c f .8,20]$. Detailed evaluations of the data using nuclear model calculations and statistical fitting procedures have also been performed for several radionuclides [cf. 21-24]. Thus the nuclear reaction cross section database for the production of innovative positron emitters appears to have considerably improved in recent years.

\subsubsection{Decay data}

In addition to the production data, some attention also needs to be paid to the radioactive decay data. Those data are of considerable significance in determining the quality of the image and the radiation dose deposited while using that radionuclide. In general, the decay data are fairly well known (cf. e.g. Evaluated Nuclear Structure and Decay Data File (ENSDF)). A problem with many of the novel positron emitters, however, is that the positron emission intensity is often rather low and not exactly known ( $c f$. Report: IAEA-INDC(NDS)-0535 (2009)), thereby causing some uncertainty in the quantification of tomographic scans. Since decay schemes of many of the medically interesting radionuclides were determined using mixtures of radionuclides, often utilising detectors with rather poor resolution, it appears worthwhile to reinvestigate some of the special radionuclides in more detail using radiochemical techniques. Many of those medical radionuclides can now be produced with very high purities; the use of ultrapure sources should thus provide accurate information on the decay data as well. Some measurements on the positron emission intensities in the decay of ${ }^{64} \mathrm{Cu},{ }^{76} \mathrm{Br},{ }^{1208} \mathrm{I}$ and ${ }^{124} \mathrm{I}$ have recently been carried out $[25,26]$. Similar measurements on several other novel positron emitters also need to be performed.

\subsection{High current targetry}

The high current irradiation technology needed for medium to large scale production of a radionuclide is rather different from the low current irradiations performed for nuclear reaction cross section measurements. In fact the development of targetry for irradiations with intense charged particle beams constitutes one of the major efforts in cyclotron production of radionuclides [cf. 27]. The loss of energy of the charged particle in the target generates a lot of heat and, if high currents are used, the power density effective at a target may reach a high value (up to a few $\mathrm{kW} \mathrm{cm}^{-2}$ ). An efficient heat transfer is thus one of the prime requirements in target construction. Several other considerations for target design are: (1) ease of chemical separation of the radioactive product, (2) high yield of the product, (3) radionuclidic purity, (4) chemical reactivity and specific activity of the desired product, and (5) recovery of enriched target material.

Whereas in the production of conventional short-lived organic positron emitters for PET, which are isotopes of light elements, gaseous and liquid targets are used, for the production of innovative positron emitters under consideration here, use is generally made of solid targetry [cf. 3,27], as it is done in the case of several SPECT radionuclides, e.g. ${ }^{67} \mathrm{Ga},{ }^{111} \mathrm{In}$ and ${ }^{201} \mathrm{Tl}$. Occasionally a gas target is also used.

Irradiation of solid material is often carried out in a conventional target system, where the front side consists of a double foil window through which He gas flows for cooling the target material. The back side of the target is cooled by flowing water. The beam impinges on the target orthogonally. Rather commonly employed solid targetry today involves preparation of a relatively thick layer (up to a few hundred $\mu \mathrm{m}$ ) of the target material via electrolytic deposition on a metal backing, and irradiations are performed with slanting beams. In other cases, where no elemental material is employed, suitably prepared alloys or intermetallic compounds are also used. Occasionally, the target material is an oxide which is spread on another metal, melted or sintered, and then used as an irradiation target.

A typical solid target system used, e.g. for the production of ${ }^{55} \mathrm{Co}$ and ${ }^{64} \mathrm{Cu}$ via the reactions ${ }^{58} \mathrm{Ni}(p, \alpha){ }^{55} \mathrm{Co}$ and ${ }^{64} \mathrm{Ni}(p, n){ }^{64} \mathrm{Cu}$, respectively, is shown in Fig. 2 [28]. The corresponding highly enriched nickel isotope is electroplated on an oval shaped gold backing which fits in a target holder designed to be exposed to the charged particle beam at an angle of $20^{\circ}$. The target holder is cooled at the back by a water jet. Beam currents of about $30 \mu \mathrm{A}$ are commonly used. With a better design of the system, beam currents of up to $300 \mu \mathrm{A}$ could be put on the target. The same target set up has also been employed in the production of ${ }^{124} \mathrm{I}$ via the ${ }^{124} \mathrm{Te}(p, n)$-reaction. In this case the target material ${ }^{124} \mathrm{TeO}_{2}$ is melted on a Pt backing (rather than electroplating on gold) which is then attached to the target holder for irradiation.

For noble gases as target material, e.g. for the production of ${ }^{38} \mathrm{~K},{ }^{81} \mathrm{Rb},{ }^{82 \mathrm{~m}} \mathrm{Rb}$ and ${ }^{83} \mathrm{Sr}$ via the reactions ${ }^{38} \mathrm{Ar}(p, n)^{38} \mathrm{~K}$, ${ }^{82} \mathrm{Kr}(p, 2 n){ }^{81} \mathrm{Rb},{ }^{82} \mathrm{Kr}(p, n){ }^{82 \mathrm{~m}} \mathrm{Rb}$ and ${ }^{82} \mathrm{Kr}\left({ }^{3} \mathrm{He}, 2 n\right){ }^{83} \mathrm{Sr}$, respectively, a typical target system used is shown in Fig. 3 [29]. The conical shaped target has a double foil window in front, which is cooled by He gas. The other accessories form a complex system for safe handling of the highly enriched rare noble gas (filling the target, irradiation and its recovery for reuse). Beam currents of about $30 \mu \mathrm{A}$ are used.

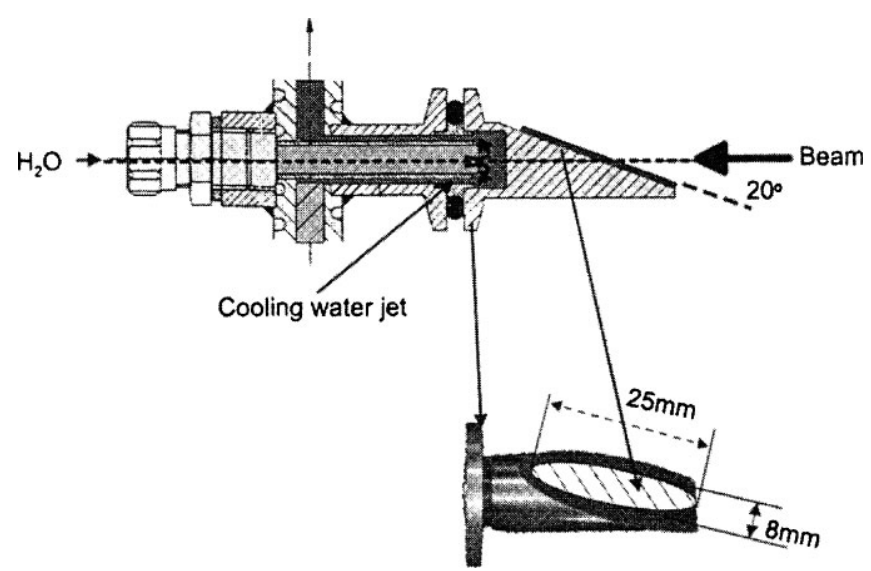

Fig. 2. Typical solid target system used for the production of ${ }^{55} \mathrm{Co}$, ${ }^{64} \mathrm{Cu}$ or ${ }^{124} \mathrm{I}$ via the nuclear reactions ${ }^{58} \mathrm{Ni}(p, \alpha){ }^{55} \mathrm{Co},{ }^{64} \mathrm{Ni}(p, n){ }^{64} \mathrm{Cu}$ and ${ }^{124} \mathrm{Te}(p, n)^{124} \mathrm{I}$, respectively. In the first two cases, the highly enriched target material is electrolytically deposited on oval shaped gold backing; in the latter case ${ }^{124} \mathrm{TeO}_{2}$ is melted on a Pt backing. The target fits in a target holder which is exposed to the proton beam at an angle of $20^{\circ}$ and is cooled at the back by a water jet (after Ref. [28]). 


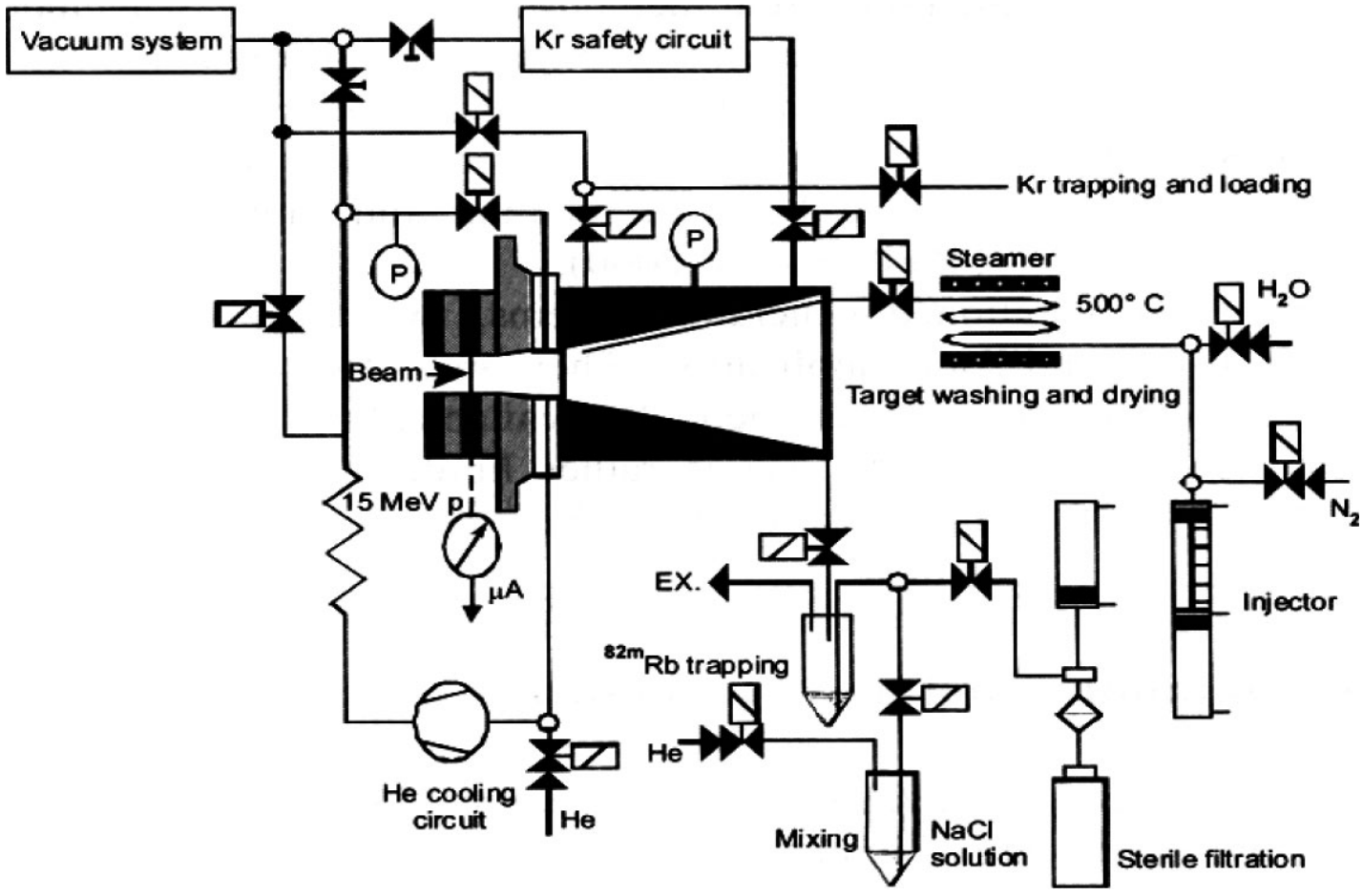

Fig. 3. Typical gas target system used for the production of ${ }^{82 \mathrm{~m}} \mathrm{Rb}$ via the nuclear reaction ${ }^{82} \operatorname{Kr}(p, n)^{82 \mathrm{~m}} \mathrm{Rb}$. The conical shaped target has a double foil window in front, which is cooled by He gas. The other accessories form a compact system for safe handling of the highly enriched rare gas. The product ${ }^{82 \mathrm{~m}} \mathrm{Rb}$ is efficiently removed from the target inner wall by introducing steam, and is collected in water. The same system has been used also for the production of ${ }^{38} \mathrm{~K},{ }^{81} \mathrm{Rb}$ or ${ }^{83} \mathrm{Sr}$ via the nuclear reactions ${ }^{38} \mathrm{Ar}(p, n)^{38} \mathrm{~K},{ }^{82} \mathrm{Kr}(p, 2 n){ }^{81} \mathrm{Rb}$ and ${ }^{82} \mathrm{Kr}\left({ }^{3} \mathrm{He}, 2 n\right)^{83} \mathrm{Sr}$, respectively; in each case proper target gas and charged particle beam energy have to be used (adapted from Ref. [29]).

After irradiation, at first the enriched target gas is recovered. The product alkali or alkaline earth metal activity remains adsorbed on the inner walls of the target. For its removal, superheated steam (at $500{ }^{\circ} \mathrm{C}$ ) is introduced in the target. On cooling, the condensed water is forced out by a stream of nitrogen and is efficiently collected in a trap. The process is repeated seven times so that $>90 \%$ of the activity is accumulated in about $2.5 \mathrm{~mL}$ of water.

\subsection{Chemical processing}

There are two major aims of chemical processing:

1. to isolate the desired radionuclide in pure form,

2. to recover the enriched material for reuse.

In production of novel positron emitters, both dry and wet chemical separation methods have been applied [ $c f$. 3]. The dry method involves distillation and thermochromatography. The best example of the dry distillation technique is furnished by separation of the increasingly important radioiodines, especially ${ }^{120 \mathrm{~g}} \mathrm{I}$ and ${ }^{124} \mathrm{I}$, from irradiated ${ }^{120} \mathrm{TeO}_{2}$ and ${ }^{124} \mathrm{TeO}_{2}$ targets, respectively, at $755^{\circ} \mathrm{C}$ [cf. 30]. Radioiodine is collected almost quantitatively and the target is regenerated (without much loss) for the next production run. Thermochromatography, on the other hand, involves the formation of a chemical species of the radioactive product which leads to its removal from the irradiated target but the vapour pressure of which is not high enough to allow its transport to large distances. The activity gets deposited in the cooler part of the thermochromatographic tube from where it is generally removed by rinsing. The method has been successfully employed in the separation of ${ }^{73} \mathrm{Se}[31,32],{ }^{75} \mathrm{Br}$ [33], ${ }^{76} \mathrm{Br}$ [34] and ${ }^{94 \mathrm{~m}} \mathrm{Tc}$ [35]. The thermochromatographic behaviour of a proton-irradiated $\mathrm{Cu}_{3}$ As-target in an oxygen atmosphere is shown in Fig. 4 [32]. The major radioactive products formed are ${ }^{73} \mathrm{Se},{ }^{74} \mathrm{As}$ and ${ }^{65} \mathrm{Zn}$ through the nuclear reactions ${ }^{75} \mathrm{As}(p, 3 n){ }^{73} \mathrm{Se},{ }^{75} \mathrm{As}(p, p n){ }^{74} \mathrm{As}$ and ${ }^{65} \mathrm{Cu}(p, n){ }^{65} \mathrm{Zn}$, respectively. The removal of $\left[{ }^{74} \mathrm{As}\right] \mathrm{As}_{2} \mathrm{O}_{3}$ is carried out at about $660{ }^{\circ} \mathrm{C}$ and that of radioselenium at about $1100{ }^{\circ} \mathrm{C}$, while ${ }^{65} \mathrm{Zn}$ remains in the quartz tube within the oven area. It should, however, be mentioned that thermochromatography only serves to concentrate the desired activity at one point. It does not necessarily give a pure product. For a cleaner separation, a subsequent wet chemical step is often necessary. On the other hand, the recovery of the enriched target material is relatively easy while using distillation or thermochromatography for the separation of the desired radioactive product.

In many production processes a wet chemical procedure is absolutely necessary. Preferentialy solvent extraction and ion-exchange techniques are used but occasionally a prior concentration of the radionuclide is achieved through coprecipitation, adsorption, etc. Several of the emerging radionuclides are separated using these methods. In the production of ${ }^{64} \mathrm{Cu}$ via the ${ }^{64} \mathrm{Ni}(p, n)$-reaction, for example, anion-exchange chromatography was applied [ $c f .14]$. In the production of ${ }^{86} \mathrm{Y}$ via the ${ }^{86} \mathrm{Sr}(p, n)$-reaction the separation proceeds in two steps [36]. The irradiated enriched ${ }^{86} \mathrm{SrCO}_{3}$ is dissolved in a small volume of conc. $\mathrm{HCl}$ and no-carrieradded ${ }^{86} \mathrm{Y}$ is coprecipitated with $\mathrm{La}(\mathrm{OH})_{3}$ by addition of $\mathrm{NH}_{4} \mathrm{OH}$ solution. The precipitate is centrifuged off and taken up in a few drops of $\mathrm{HCl}$. The separation of radioyttrium from inactive La is then effected through ion-exchange chromatography by elution with $\alpha$-hydroxyisobutyric acid, 

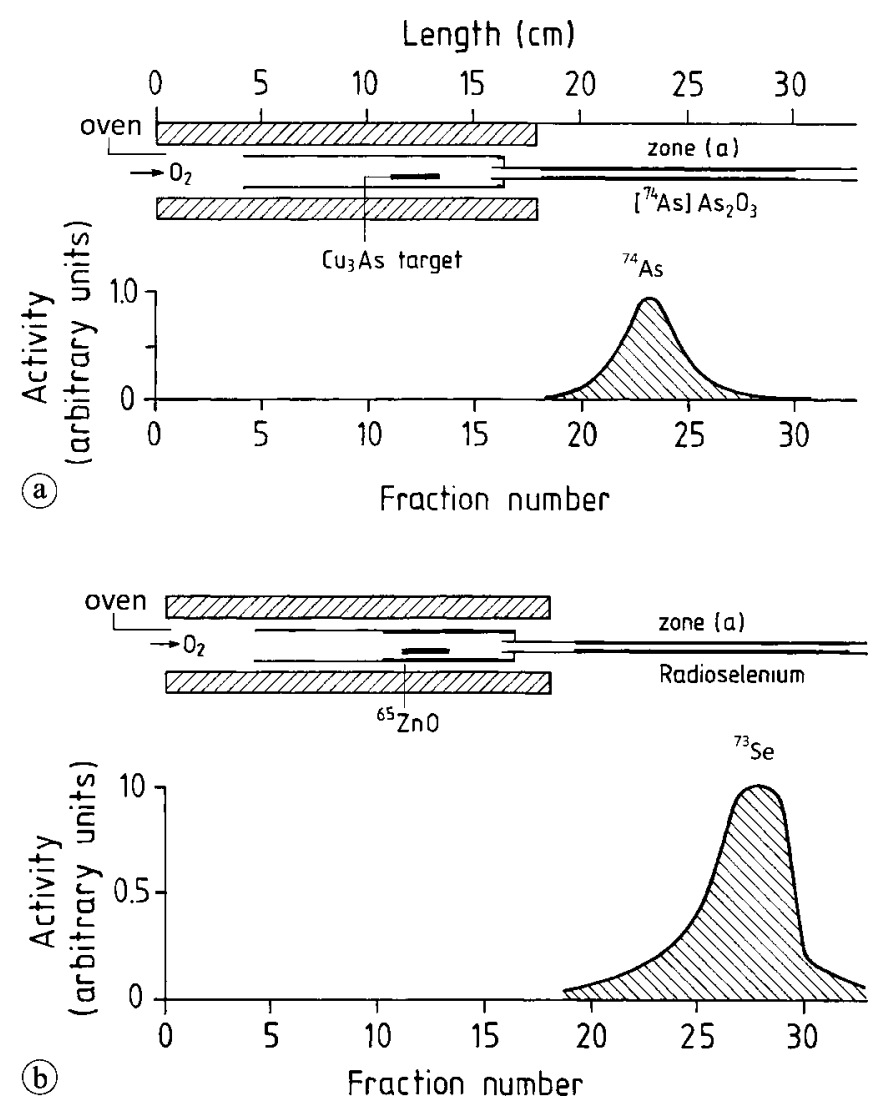

Fig. 4. Two step thermochromatographic procedure for separation of radioselenium from the $\mathrm{Cu}_{3} \mathrm{As}$-target irradiated with protons (adapted from Ref. [32]). (a) Removal of $\left[{ }^{74} \mathrm{As}\right] \mathrm{As}_{2} \mathrm{O}_{3}$ from the target in an oxygen stream at $660^{\circ} \mathrm{C}$ to zone (a). The deposition profile was determined using the $595 \mathrm{keV} \gamma$-ray of ${ }^{74} \mathrm{As}$. (b) Replacement of the external quartz tube by another quartz tube. Removal of radioselenium at $900-1100{ }^{\circ} \mathrm{C}$ to zone (a). The activity profile was determined using the $361 \mathrm{keV} \gamma$-ray of ${ }^{73} \mathrm{Se}$. The volatalized ${ }^{65} \mathrm{ZnO}$ remains in the quartz tube within the oven area.

either by normal pressure [36] or in combination with high performance liquid chromatography [37]. Fig. 5 shows the elution profile of radioyttrium. The activity amounting to several $\mathrm{GBq}$ is collected in only $150 \mu \mathrm{L}$ solution. The separation of ${ }^{52} \mathrm{Mn},{ }^{52} \mathrm{Fe},{ }^{55} \mathrm{Co},{ }^{89} \mathrm{Zr}$, etc. is also carried out via ion-exchange chromatography.

\subsection{Remote handling}

In a real production run the aim is to achieve the maximum batch yield of the radionuclide (with the minimum level of the radionuclidic impurities). The amount of radioactivity involved is rather high (often up to $100 \mathrm{GBq}$ ). All the unit operations, such as removal of the irradiated target from the beamline, its transfer to the radiochemistry laboratory, and finally the chemical processing, need to be handled remotely in order to decrease the radiation dose to the researcher. Some of those operations even demand automated methods to avoid human errors. Many of the novel positron emitters are still at the experimental stage of production for local use. On the other hand, a few of them have passed that stage; their large scale production now appears necessary and useful. The examples are: ${ }^{64} \mathrm{Cu},{ }^{86} \mathrm{Y}$ and ${ }^{124} \mathrm{I}$. In those cases the need for development of remotely controlled or even automated methods of production is imminent.

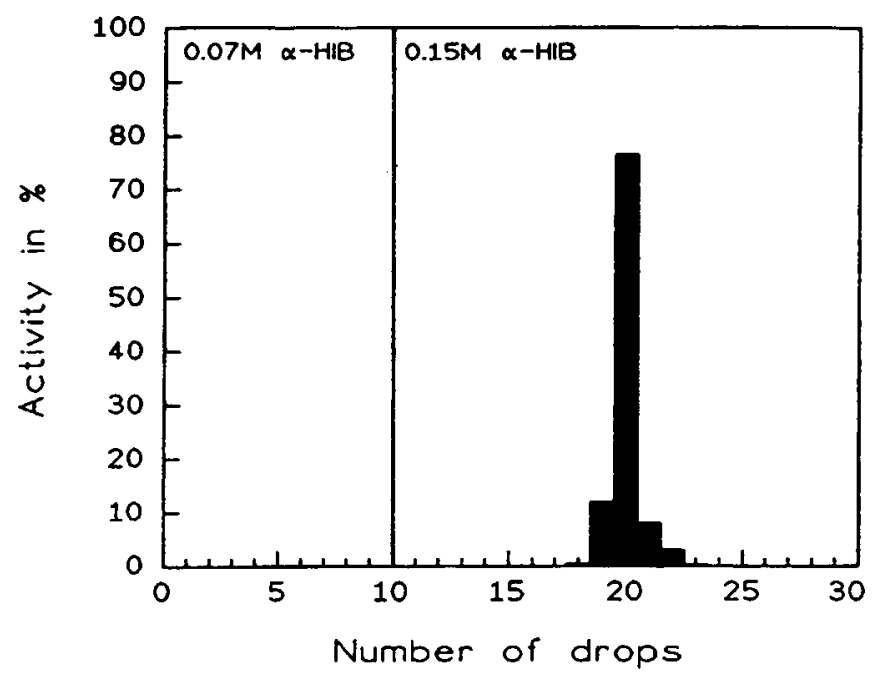

Fig. 5. Elution diagram of radioyttrium from a column filled with Aminex A5 cation-exchanger $(4 \mathrm{~mm} \varnothing \times 40 \mathrm{~mm})$. The no-carrieradded ${ }^{86} \mathrm{Y}$, coprecipitated with $\mathrm{La}(\mathrm{OH})_{3}$, was dissolved in a small volume of $\mathrm{HCl}$ and transferred to the above column. Elution was done with $\alpha$-hydroxyisobutyric acid ( $\alpha$-HIB). The ${ }^{86} \mathrm{Y}$ activity was collected in a few drops (after Ref. [36]).

\subsection{Quality control of the product}

An important step in a chain of operations for the production of a novel radionuclide consists of quality assurance of the obtained product. In general, four characteristics need to be considered. These are radionuclidic purity, radiochemical purity, chemical purity and specific activity. A brief discussion of each item is given below.

The radionuclidic purity means the absence of any other radionuclide. This is achieved via the choice of a suitable nuclear process and energy range, combined with a clean chemical separation. The radionuclide ${ }^{124} \mathrm{I}$, for example can be produced via a large number of reactions [cf. 20]. However, its production is carried out today mainly using the ${ }^{124} \mathrm{Te}(p, n)$-reaction on a highly enriched ${ }^{124} \mathrm{TeO}_{2}$ target over the energy range of $E_{\mathrm{p}}=14 \rightarrow 9 \mathrm{MeV}$. Although the yield of this process is not very high, the resulting product is very pure $\left({ }^{125} \mathrm{I}\right.$ impurity $\left.<0.1 \%\right)$.

The radiochemical purity means that the radiochemically separated product is in the form of one major chemical species. In the case of a solid target the separated radionuclide is generally brought into a desired radiochemical form through oxidation/reduction cycles. The radiochemical purity is generally tested by radiochromatographic methods, such as thin layer chromatography (TLC), e.g. in production of ${ }^{94 \mathrm{~m}} \mathrm{Tc}$ [cf. 35], high performance liquid chromatography (HPLC), e.g. in production of ${ }^{120 g} \mathrm{I}$ and ${ }^{124} \mathrm{I}[c f .30]$, and ionexchange chromatography, e.g. in production of ${ }^{86} \mathrm{Y}[c f .36$, 37]. A typical example relevant to ${ }^{94 \mathrm{~m}} \mathrm{Tc}$ production [35] is shown in Fig. 6. The thermochromatographically separated fraction was dissolved in a small volume of $10^{-4} \mathrm{M} \mathrm{NaOH}$ and the solution subjected to TLC analysis. Two species were detected (Fig. 6a), one representing $\mathrm{TcO}_{4}{ }^{-}\left(R_{\mathrm{f}}=0.95\right)$ and amounting to $80-90 \%$, and the other a radiochemical impurity $\left(R_{\mathrm{f}} \approx 0\right)$ with the contribution of $5-10 \%$. When the solution was passed through a small alumina column, it was purified; the technetium then occurred almost $100 \%$ in the chemical form of pertechnetate (Fig. 6b). 


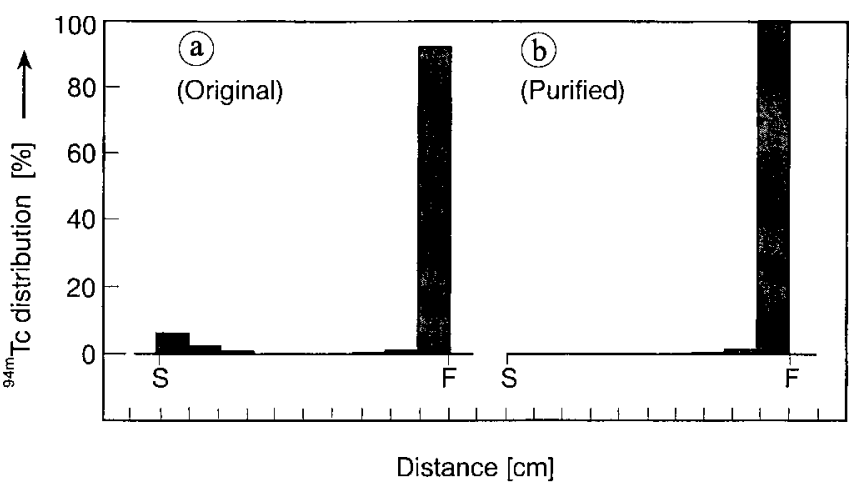

Fig. 6. Radiochemical quality control of the radiotechnetium solution (after dissolution of the thermochromatographically separated technetium fraction from a $\mathrm{MoO}_{3}$ target) in $10^{-4} \mathrm{M} \mathrm{NaOH}$ : (a) original solution, (b) after final purification using alumina column chromatography. $\mathrm{S}$ denotes starting point and $\mathrm{F}$ the final position. Thin layer chromatography was done on Merck TLC plates (silica gel $60 \mathrm{~F}_{254}$ ), and acetone was used as solvent system (after Ref. [35]).

The chemical purity means the absence of inactive impurities which are generally introduced via the chemical reagents used in the production of the radionuclide. Apart from their possible toxicity, those impurities may form complexes with the radionuclide, thereby decreasing its reactivity. The chemical purity appears to be more important in the case of metal radionuclides, such as novel positron emitters, than for radionuclides used in the labelling of organic compounds. For checking the chemical purity one or more of the standard techniques, such as atomic absorption (AA) spectroscopy, ultraviolet (UV) or infrared (IR) detection, inductively coupled plasma-mass spectrometry (ICP-MS) and polarography are used.

The specific activity is defined as the radioactivity per unit mass of the product. Cyclotron production of radionuclides leads inherently to high specific activity products, unless some carrier inadvertently gets introduced by impure target material during the chemical processing stage. The co-production of stable or longer-lived species also needs to be considered since it would decrease the specific activity of the desired product. In case of metal radionuclides it is quite a serious consideration; very pure reagents and clean working methods are absolutely needed. For estimating the specific activity, generally the radioactivity of the whole batch is measured in an ionisation chamber and the mass is determined using a sensitive detection method, such as UV, IR, refractive index or conductivity measurement.

It should be mentioned that the above discussed four quality assurance tests refer to the radionuclide in its original form. They are crucial with respect to further processing of the radionuclide. If the radionuclide is converted into a radiopharmaceutical for human use, several further stringent tests, like those for sterility, apyrogenicity and toxicity, also become mandatory.

\subsection{Suitability of novel positron emitters for PET imaging}

In contrast to standard positron emitters, PET imaging with novel or non-standard positron emitters is often associated with two major problems:

1. High end-point energy of the positron,

\section{Emission of $\gamma$-rays accompanying the positron.}

These may cause reduction of spatial resolution and blurring of the image. PET phantom measurements are therefore needed to demonstrate the suitability of a novel positron emitter for imaging purposes [ $c f .38-44]$. The high positron end-point energies of ${ }^{66} \mathrm{Ga},{ }^{76} \mathrm{Br}$ and ${ }^{120 g} \mathrm{I}$ (in each case around $4 \mathrm{MeV}$ ), for example, limit the use of those radionuclides. Similarly the large number of $\gamma$-rays associated with several radionuclides, e.g. ${ }^{76} \mathrm{Br}$ and ${ }^{86} \mathrm{Y}$, cause considersable distortion of images. However, with the development of efficient algorithms these effects can be often efficiently corrected [cf. 38-44]. Thus, prior to application, the correction factor needs to be determined individually for each novel positron emitter through PET phantom measurements.

\section{Production of novel positron emitters}

Several types of accelerators and nuclear reactions have been used for the production of novel radionuclides. A discussion is given below.

\subsection{Production using low-energy reactions}

Most of the novel positron emitters have been developed at laboratories where standard positron emission tomography facilities already existed. Since at PET centres generally only a small-sized cyclotron is available (with $E<20 \mathrm{MeV}$ ), almost all of the development work has been carried out using those cyclotrons. A brief overview of the production routes using low-energy reactions is given in Table 1 [cf. 13-19, 28-30, 34-37, 45-50, 53-92]. In each case, except for ${ }^{45} \mathrm{Ti},{ }^{52} \mathrm{Mn},{ }^{72} \mathrm{As},{ }^{89} \mathrm{Zr}$ and ${ }^{90} \mathrm{Nb}$, highly enriched target material was used. The suitable energy range, the thick target yield calculated from the excitation function, the expected radionuclidic impurities and the relevant references are given. For production, in general, solid targetry was used, except for the ${ }^{38} \operatorname{Ar}(p, n){ }^{38} \mathrm{~K},{ }^{78} \mathrm{Kr}(p, \alpha){ }^{75} \mathrm{Br}$, ${ }^{78} \mathrm{Kr}(d, \alpha){ }^{76} \mathrm{Br}$ and ${ }^{82} \mathrm{Kr}(p, n){ }^{82 \mathrm{~m}} \mathrm{Rb}$ reactions where gas targetry was employed. Technical development work has been performed in many institutes around the world but several of the radionuclides have been investigated only in one or two laboratories, with limited application. Radionuclides of more general interest are ${ }^{55} \mathrm{Co},{ }^{61} \mathrm{Cu},{ }^{72} \mathrm{As},{ }^{76} \mathrm{Br},{ }^{89} \mathrm{Zr},{ }^{94 \mathrm{~m}} \mathrm{Tc}$ and ${ }^{120 \mathrm{~g}} \mathrm{I}$. Their production methods have been well worked out $[c f .14,34,35,68-70,81-89]$ and radionuclidically pure products are available for medical development work. On the other hand, three novel positron emitters, namely ${ }^{64} \mathrm{Cu}$, ${ }^{86} \mathrm{Y}$ and ${ }^{124} \mathrm{I}$, have become of wide interest and are now in great demand. Their production is discussed in some detail below.

The radionuclide ${ }^{64} \mathrm{Cu}$ emits low-energy positrons, has no disturbing $\gamma$-ray and has a suitable half-life to study slow metabolic processes. The production route ${ }^{64} \mathrm{Ni}(p, n){ }^{64} \mathrm{Cu}$, originally suggested by the Jülich group [14], has been further developed in several other laboratories [ $c f$. 45-50]. In a recent work sophisticated targetry calculations have been done [50]. Batches of about $40 \mathrm{GBq}$ are now routinely produced. Several intermediate energy reactions have also been investigated for the production of ${ }^{64} \mathrm{Cu}$ [for review $c f .8,21]$, but the levels of impurities are higher. 
Table 1. Novel PET radionuclides produced at low-energy cyclotrons $(E<20 \mathrm{MeV})$.

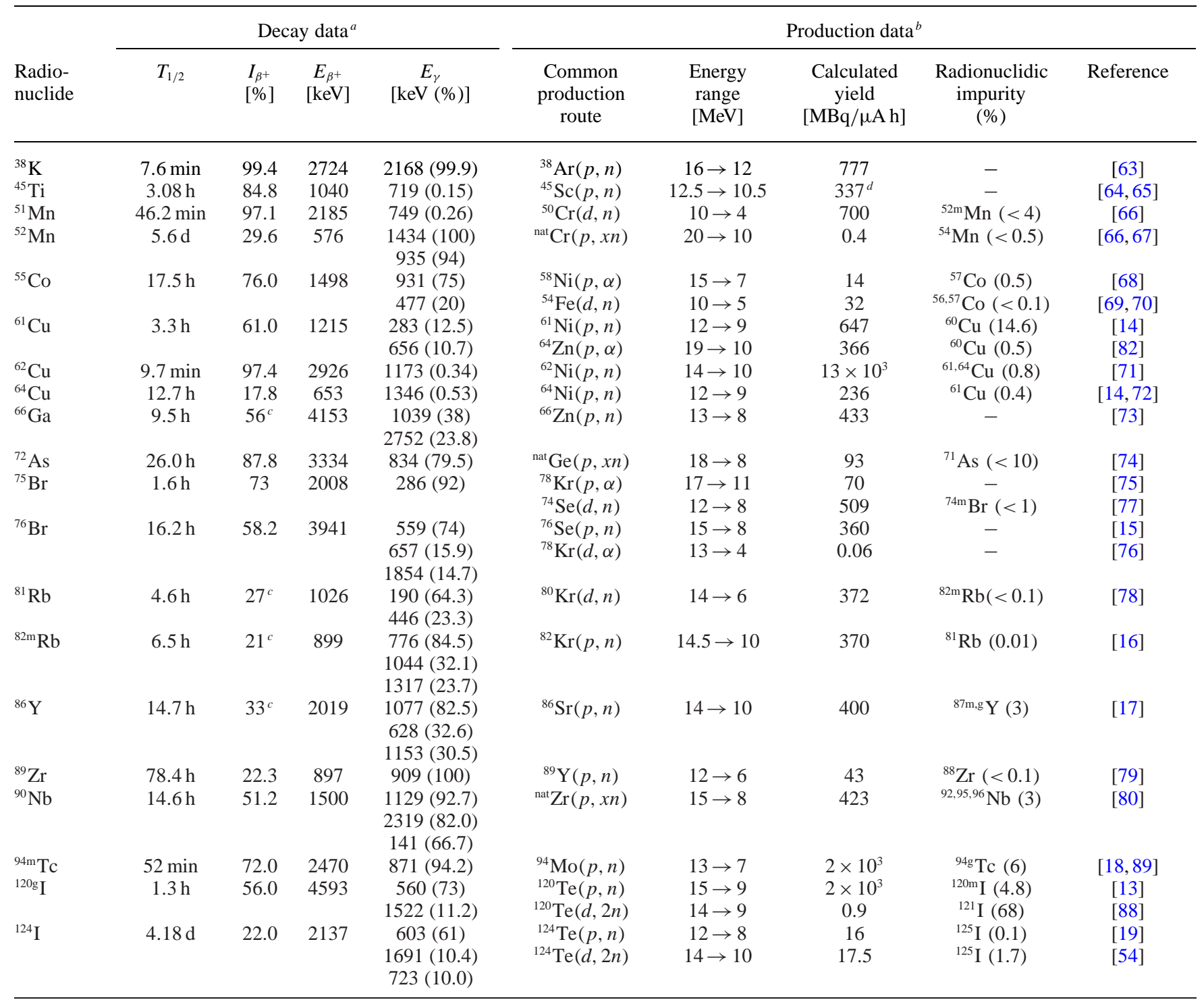

a: Decay data were mostly taken from ENSDF. For ${ }^{64} \mathrm{Cu},{ }^{76} \mathrm{Br},{ }^{120 \mathrm{~g}} \mathrm{I}$ and ${ }^{124} \mathrm{I}$ the $I_{\beta^{+}}$values were adopted from Refs. [25, 26].

b: Using highly enriched isotope as target material, unless monoisotopic or denoted otherwise.

c: $I_{\beta^{+}}$value has rather large uncertainty.

d: Experimental value.

Small amounts of ${ }^{64} \mathrm{Cu}$ can also be produced using the deuteron induced reactions on ${ }^{64} \mathrm{Zn}$ and ${ }^{\text {nat }} \mathrm{Zn}[c f .51,52]$. Due to extensive demand for this radionuclide for radioimmunotherapy, attempts are underway to commercialize its production.

The radionuclide ${ }^{\mathbf{1 2 4}} \mathbf{I}$ is both a diagnostic and a therapeutic agent. It was originally produced via the ${ }^{124} \mathrm{Te}(d, 2 n)^{124} \mathrm{I}$ reaction [53]; accurate cross section data were measured later [54]. Several other reactions have also been investigated [cf. 20-24]. However, due to the high level of the ${ }^{125} \mathrm{I}\left(T_{1 / 2}=60.0 \mathrm{~d}\right)$ impurity associated with those processes, the method ${ }^{124} \mathrm{Te}(p, n)^{124} \mathrm{I}$ suggested by our group [19], was found to be more suitable. With this process the ${ }^{125} \mathrm{I}$ impurity level is $<0.1 \%$. Today almost all the laboratories use this method [ $c f .55-58]$. It involves irradiation of a ${ }^{124} \mathrm{TeO}_{2}$ target and removal of radioiodine by a dry distillation process [ $c f .30]$. The yield is rather low and the product is somewhat expensive. Nonetheless, due to increasing demands for this radionuclide, efforts are underway to produce this radionuclide in larger qunatities.

The production of ${ }^{86} \mathbf{Y}$ was also investigated in detail at Jülich and the reaction ${ }^{86} \operatorname{Sr}(p, n)^{86} \mathrm{Y}$ was found to be the most suitable $[17,36,37]$. The irradiated ${ }^{86} \mathrm{SrCO}_{3}$ target was dissolved in a small volume of conc. $\mathrm{HCl}$ and the separation of radioyttrium was carried out, as mentioned above, by coprecipitation followed by ion-exchange [36]; later in combination with HPLC [37]. Four other methods of separation have also been applied: one involves electrolysis [59, $90,91]$, the other one multiple column chromatography [60], the third one solvent extraction [cf. 61], and the fourth one a simple precipitation of the target material [62,92]. The electrolytic method appears to be more promising. The radionuclide ${ }^{86} \mathrm{Y}$ obtained has a purity of about $99 \%$. The target material ${ }^{86} \mathrm{Sr}$ is recovered easily and, since the suggested proton energy of $14 \mathrm{MeV}$ is below the threshold of the ${ }^{86} \mathrm{Sr}(p, p n)^{85} \mathrm{Sr}$ reaction, the recovered target material is 
free of any radioactive impurity. In contrast, the intermediate energy reactions used for the production of ${ }^{86} \mathrm{Y}$, e.g. ${ }^{87} \operatorname{Sr}(p, 2 n){ }^{86} \mathrm{Y}$ and ${ }^{88} \operatorname{Sr}(p, 3 n){ }^{86} \mathrm{Y}$ reactions, lead to high ${ }^{87} \mathrm{Y}$ impurity (see below).

The radionuclide ${ }^{86} \mathrm{Y}$ has become the most suitable positron emitter for quantification of radiation dosimetry of ${ }^{90} \mathrm{Y}$-labelled therapeuticals. The demand for this radionuclide is also increasing and so its large scale production is being planned at several centres.

\subsection{Production using intermediate energy reactions}

Despite the above discussed capability of low-energy nuclear reactions on highly enriched target isotopes to produce many novel positron emitters there are some radionuclides which can be produced exclusively or alternatively using intermediate-energy reactions. A list of those radionuclides is given in Table 2 [ $c f .93-122]$. Some of the examples are: ${ }^{56} \mathrm{Fe}(p, 2 n){ }^{55} \mathrm{Co},{ }^{76} \mathrm{Se}(p, 2 n){ }^{75} \mathrm{Br},{ }^{111} \mathrm{Cd}(p, 2 n){ }^{1108} \mathrm{In}$, ${ }^{125} \mathrm{Te}(p, 2 n){ }^{124} \mathrm{I},{ }^{40} \mathrm{Ar}(p, 3 n){ }^{38} \mathrm{~K},{ }^{75} \mathrm{As}(p, 3 n){ }^{73} \mathrm{Se},{ }^{79} \mathrm{Br}(p$, $3 n){ }^{77} \mathrm{Kr},{ }^{85} \mathrm{Rb}(p, 3 n)^{83} \mathrm{Sr},{ }^{122} \mathrm{Te}(p, 3 n){ }^{120 g} \mathrm{I},{ }^{55} \mathrm{Mn}(p, 4 n){ }^{52} \mathrm{Fe}$ and ${ }^{68} \mathrm{Zn}(p, \alpha n){ }^{64} \mathrm{Cu}$. The $(p, 2 n)$ reaction can generally be performed at a $30 \mathrm{MeV}$ cyclotron. For other reactions, higher proton energies, in some cases up to $100 \mathrm{MeV}$, are needed. With the emission of a large number of nucleons, the nuclear data work becomes rather extensive. As a typical example, the excitation functions of several measured reactions in the interaction of protons with ${ }^{85} \mathrm{Rb}$ [123] are shown in Fig. 7. Evidently, for the production of a desired radionuclide, a narrow energy window has to be chosen. In the example given above, the suitable energy range for the production of the novel positron emitter ${ }^{83} \mathrm{Sr}$ amounts to $E_{\mathrm{p}}=38 \rightarrow 30 \mathrm{MeV}$. Similarly, the radionuclide ${ }^{82} \mathrm{Sr}$ (the parent nuclide used in the preparation of the standard ${ }^{82} \mathrm{Sr} /{ }^{82} \mathrm{Rb}$ generator system) is advantageously produced over the energy range of $E_{\mathrm{p}}=70 \rightarrow 50 \mathrm{MeV}$.

Although in the intermediate energy region mostly protons are available and are also preferably used, other charged particles like deuterons, ${ }^{3} \mathrm{He}$ - and $\alpha$-particles may also induce a few useful reactions. For example, the intermediate energy deuterons could be useful in the production of ${ }^{64} \mathrm{Cu}$ via the ${ }^{\text {nat }} \mathrm{Zn}(d, x)$-process $[100,101]$ and ${ }^{73} \mathrm{Se}$ via the ${ }^{75} \mathrm{As}(d, 4 n)$-reaction [102]. Similarly, ${ }^{75} \mathrm{Br}$ and ${ }^{76} \mathrm{Br}$ are still produced via the ${ }^{75} \mathrm{As}\left({ }^{3} \mathrm{He}, 3 n\right){ }^{75} \mathrm{Br}$ and ${ }^{75} \mathrm{As}\left({ }^{3} \mathrm{He}, 2 n\right){ }^{76} \mathrm{Br}$ reactions, respectively, because of the difficulty in target construction while using enriched ${ }^{76} \mathrm{Se}$. In some other cases, e.g. ${ }^{52} \mathrm{Fe},{ }^{77} \mathrm{Kr},{ }^{83} \mathrm{Sr},{ }^{86} \mathrm{Y}$ and ${ }^{94 \mathrm{~m}} \mathrm{Tc}$, the use of the ${ }^{3} \mathrm{He}$-particle beam is optional, the yield being lower than that using the corresponding $(p, x n)$ reaction. As far as the $\alpha$-particle beam is concerned, to date the radionuclides ${ }^{30} \mathrm{P}$ and ${ }^{38} \mathrm{~K}$ have been exclusively produced in GBq amounts by an $(\alpha, n)$ reaction $[c f .124,125]$. In case of non-availability of $40 \mathrm{MeV}$ protons, the utility of the ${ }^{70} \mathrm{Ge}(\alpha, n)^{73} \mathrm{Se}$ reaction in the production of ${ }^{73} \mathrm{Se}$ in $\mathrm{GBq}$ amounts has also been demonstrated [31]. The use of the ${ }^{\text {nat }} \mathrm{Cu}(\alpha, x)^{66} \mathrm{Ga}$ and ${ }^{\text {nat }} \mathrm{Sr}(\alpha, x)^{89} \mathrm{Zr}$ reactions to produce ${ }^{66} \mathrm{Ga}$ and ${ }^{89} \mathrm{Zr}$ is again optional [115, 133], since the yields of the commonly used ${ }^{66} \mathrm{Zn}(p, n)^{66} \mathrm{Ga}$ and ${ }^{89} \mathrm{Y}(p, n)^{89} \mathrm{Zr}$ processes are much higher. The possibility of production of ${ }^{82} \mathrm{Sr}$ via the ${ }^{82} \mathrm{Kr}(\alpha, 4 n)^{82} \mathrm{Sr}$ reaction has also been investigated [126]. Though less effective,
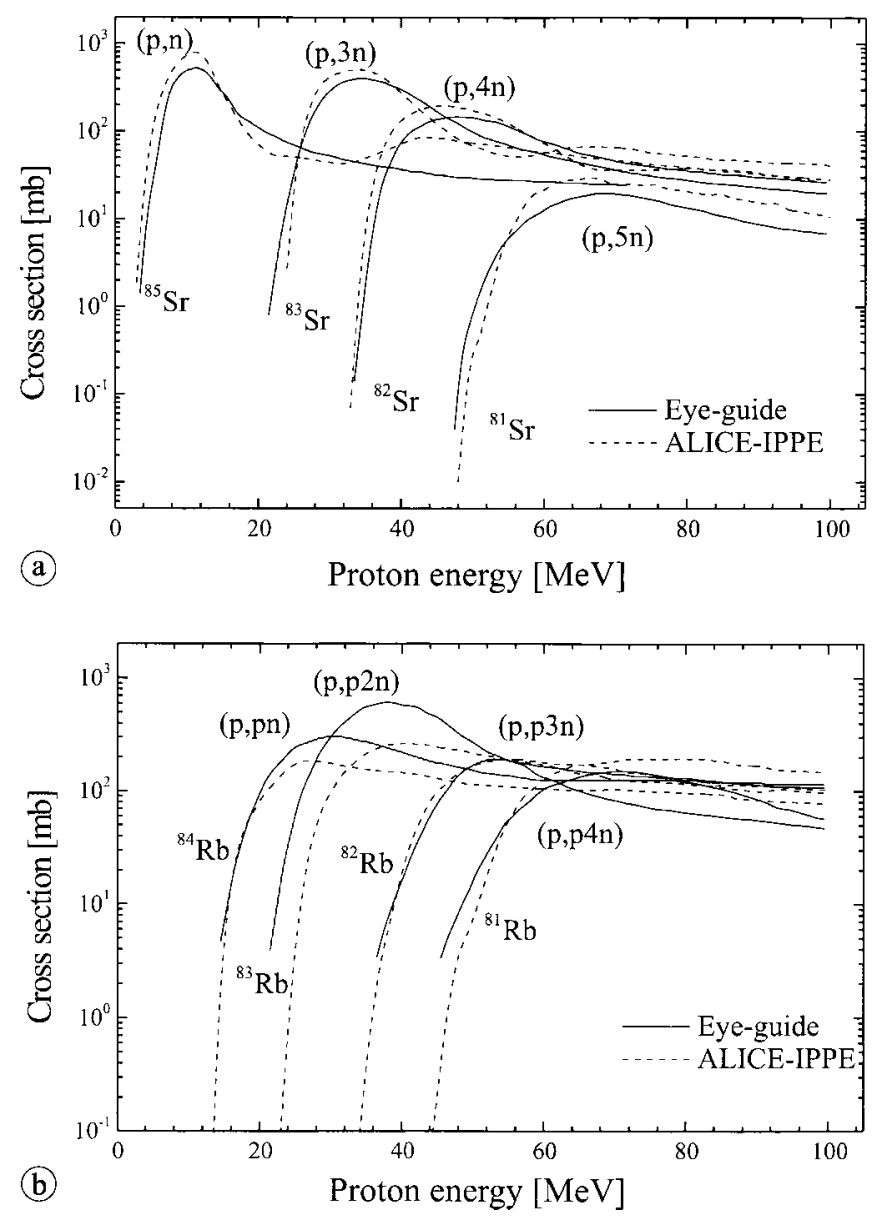

Fig.7. Excitation functions of proton induced nuclear reactions on ${ }^{85} \mathrm{Rb}$. (a) ${ }^{85} \mathrm{Rb}(p, x n)$-reactions leading to the formation of the radionuclides ${ }^{85} \mathrm{Sr},{ }^{83} \mathrm{Sr},{ }^{82} \mathrm{Sr}$ and ${ }^{81} \mathrm{Sr}$. (b) ${ }^{85} \mathrm{Rb}(p, p x n)$-reactions giving rise to the radionuclides ${ }^{84} \mathrm{Rb},{ }^{83} \mathrm{Rb},{ }^{82} \mathrm{Rb}$ and ${ }^{81} \mathrm{Rb}$. The experimental data $[112,123]$ are shown as eye-guide solid curves and the results of calculations using the nuclear reaction model code ALICE-IPPE [123] as dotted curves. With increasing projectile energy the number of radioactive products formed increases considerably.

it could be an alternative method to the ${ }^{85} \mathrm{Rb}(p, 4 n)^{82} \mathrm{Sr}$ process if the available proton energy is below $70 \mathrm{MeV}$. Very recently the ${ }^{123} \mathrm{Sb}(\alpha, 3 n)^{124}$ I reaction was carefully studied [122] and it was concluded that irradiation of ${ }^{123} \mathrm{Sb}$ with $45 \mathrm{MeV} \alpha$-particles, especially in a parasitic position, could lead to appreciable quantities of the radionuclide ${ }^{124} \mathrm{I}$.

The above discussion shows that intermediate energy cyclotrons have great potential for production of novel positron emitters. For most of the listed radionuclides, sufficient quantities for medical applications have been produced. However, a critical look at the various processes is necessary. The radionuclides ${ }^{30} \mathrm{P}$ and ${ }^{38} \mathrm{~K}$ are short-lived and can only be locally used. The radionuclides ${ }^{52} \mathrm{Mn}$, ${ }^{55} \mathrm{Co},{ }^{64} \mathrm{Cu},{ }^{66} \mathrm{Ga},{ }^{76} \mathrm{Br},{ }^{86} \mathrm{Y},{ }^{89} \mathrm{Zr},{ }^{94 \mathrm{~m}} \mathrm{Tc}$ and ${ }^{1200 \mathrm{I}}$ produced via intermediate energy reactions ( $c f$. Table 2 and also Refs. [127-130]) often contain larger radionuclidic impurities than in the case of low-energy production reactions, so that their preferred routes are those given in Table 1. This has been clearly demonstrated in the case of ${ }^{55} \mathrm{Co},{ }^{86} \mathrm{Y}$ and ${ }^{120 g} \mathrm{I}$. Whereas the ${ }^{56} \mathrm{Fe}(p, 2 n){ }^{55} \mathrm{Co}$ [98], ${ }^{88} \mathrm{Sr}(p, 3 n)^{86} \mathrm{Y}$ [116] and ${ }^{122} \mathrm{Te}(p, 3 n){ }^{120 \mathrm{~g}} \mathrm{I}$ [12] reactions give much higher yields of the products than the low-energy 
Table 2. Novel PET radionuclides produced using intermediate energy cyclotrons.

\begin{tabular}{|c|c|c|c|c|c|c|c|c|c|}
\hline \multirow[b]{2}{*}{$\begin{array}{l}\text { Radio- } \\
\text { nuclide }\end{array}$} & \multicolumn{4}{|c|}{ Decay data ${ }^{a}$} & \multicolumn{5}{|c|}{ Production data } \\
\hline & $T_{1 / 2}$ & $\begin{array}{l}I_{\beta^{+}} \\
{[\%]}\end{array}$ & $\begin{array}{c}E_{\beta^{+}} \\
{[\mathrm{keV}]}\end{array}$ & $\begin{array}{c}E_{\gamma} \\
{[\operatorname{keV}(\%)]}\end{array}$ & $\begin{array}{l}\text { Common } \\
\text { production } \\
\text { route }\end{array}$ & $\begin{array}{l}\text { Energy } \\
\text { range } \\
{[\mathrm{MeV}]}\end{array}$ & $\begin{array}{c}\text { Calculated } \\
\text { yield } \\
{[\mathrm{MBq} / \mu \mathrm{Ah}]}\end{array}$ & $\begin{array}{c}\text { Radionuclidic } \\
\text { impurity } \\
(\%)\end{array}$ & Reference \\
\hline${ }^{30} \mathrm{P}$ & $2.5 \mathrm{~min}$ & 99.9 & 3245 & $2235(0.06)$ & ${ }^{27} \mathrm{Al}(\alpha, n)$ & $28 \rightarrow 10$ & 740 & - & [93] \\
\hline${ }^{38} \mathrm{~K}$ & $7.6 \mathrm{~min}$ & 99.4 & 2724 & 2168 (99.9) & $\begin{array}{l}{ }^{35} \mathrm{Cl}(\alpha, n) \\
{ }^{40} \mathrm{Ar}(p, 3 n)\end{array}$ & $\begin{array}{l}22 \rightarrow 7 \\
39 \rightarrow 23\end{array}$ & $\begin{array}{l}270 \\
550\end{array}$ & $\begin{array}{l}- \\
-\end{array}$ & $\begin{array}{l}{[94]} \\
{[95]}\end{array}$ \\
\hline${ }^{52} \mathrm{Mn}$ & $5.6 \mathrm{~d}$ & 29.6 & 576 & $\begin{array}{c}1434(100) \\
935(94)\end{array}$ & ${ }^{52} \mathrm{Cr}\left({ }^{3} \mathrm{He}, t\right)$ & $36 \rightarrow 10$ & 5.6 & ${ }^{54} \mathrm{Mn}(0.8)$ & [96] \\
\hline${ }^{52} \mathrm{Fe}$ & $8.3 \mathrm{~h}$ & 55.5 & 806 & $169(99.2)$ & $\begin{array}{c}{ }^{55} \mathrm{Mn}(p, 4 n) \\
{ }^{52} \mathrm{Cr}\left({ }^{3} \mathrm{He}, 3 n\right)\end{array}$ & $\begin{aligned} 100 & \rightarrow 60 \\
36 & \rightarrow 17\end{aligned}$ & $\begin{array}{l}22 \\
1.3\end{array}$ & $\begin{array}{l}{ }^{55} \mathrm{Fe}(<2) \\
{ }^{55} \mathrm{Fe}(<0.01)\end{array}$ & $\begin{array}{l}{[97]} \\
{[96]}\end{array}$ \\
\hline${ }^{55} \mathrm{Co}$ & $17.6 \mathrm{~h}$ & 76.0 & 1498 & $\begin{array}{l}931(75) \\
477(20)\end{array}$ & ${ }^{56} \mathrm{Fe}(p, 2 n)$ & $32 \rightarrow 18$ & 130 & ${ }^{56} \mathrm{Co}(2)$ & [98] \\
\hline${ }^{64} \mathrm{Cu}$ & $12.7 \mathrm{~h}$ & 17.8 & 653 & $1346(0.53)$ & $\begin{array}{c}{ }^{68} \operatorname{Zn}(p, \alpha n)^{b} \\
\text { nat } \operatorname{Zn}(d, x)\end{array}$ & $\begin{array}{l}30 \rightarrow 21 \\
25 \rightarrow 10\end{array}$ & $\begin{array}{c}116 \\
57\end{array}$ & $\begin{array}{l}{ }^{67} \mathrm{Cu}(<0.1) \\
{ }^{67} \mathrm{Cu}(<1)\end{array}$ & $\begin{array}{c}{[99]} \\
{[100,101]}\end{array}$ \\
\hline${ }^{66} \mathrm{Ga}$ & $9.5 \mathrm{~h}$ & $56^{c}$ & 4153 & $\begin{array}{c}1039(38) \\
2752(23.8)\end{array}$ & ${ }^{\mathrm{nat}} \mathrm{Cu}(\alpha, x)$ & $20 \rightarrow 10$ & 33 & ${ }^{67} \mathrm{Ga}(1.2)$ & [133] \\
\hline${ }^{73} \mathrm{Se}$ & $7.1 \mathrm{~h}$ & 65.4 & 1651 & $\begin{array}{c}67(70) \\
361(97)\end{array}$ & $\begin{array}{c}{ }^{75} \mathrm{As}(p, 3 n) \\
{ }^{75} \mathrm{As}(d, 4 n) \\
{ }^{\text {nat }} \mathrm{Ge}\left({ }^{3} \mathrm{He}, x n\right) \\
{ }^{\text {nat }} \mathrm{Ge}(\alpha, x n) \\
{ }^{n a t} \mathrm{Br}(p, x)\end{array}$ & $\begin{array}{l}40 \rightarrow 30 \\
45 \rightarrow 33 \\
36 \rightarrow 13 \\
28 \rightarrow 13 \\
63 \rightarrow 42\end{array}$ & $\begin{array}{c}1.4 \times 10^{3} \\
650 \\
37 \\
26 \\
81\end{array}$ & $\begin{array}{c}{ }^{72,75} \mathrm{Se}(<0.2) \\
{ }^{72,75} \mathrm{Se}(<0.3) \\
{ }^{72,75} \mathrm{Se}(2.0) \\
{ }^{72,75} \mathrm{Se}(1.0) \\
{ }^{75} \mathrm{Se}(1.2)\end{array}$ & $\begin{array}{l}{[102]} \\
{[102]} \\
{[103]} \\
{[103]} \\
{[104]}\end{array}$ \\
\hline${ }^{75} \mathrm{Br}$ & $1.6 \mathrm{~h}$ & 73 & 2008 & $286(92)$ & $\begin{array}{l}{ }^{75} \mathrm{As}\left({ }^{3} \mathrm{He}, 3 n\right) \\
{ }^{76} \mathrm{Se}(p, 2 n)^{b} \\
{ }^{77} \mathrm{Se}(p, 3 n)^{b}\end{array}$ & $\begin{array}{l}36 \rightarrow 25 \\
24 \rightarrow 21 \\
60 \rightarrow 40\end{array}$ & $\begin{array}{c}278 \\
1.2 \times 10^{3} \\
2 \times 10^{3}\end{array}$ & $\begin{array}{l}{ }^{76} \mathrm{Br}(1.7) \\
{ }^{76} \mathrm{Br}(2) \\
{ }^{76} \mathrm{Br}(25)\end{array}$ & $\begin{array}{c}{[105]} \\
{[106-108]} \\
{[108]}\end{array}$ \\
\hline${ }^{76} \mathrm{Br}$ & $16.0 \mathrm{~h}$ & 58.2 & 3941 & $\begin{array}{c}559(74) \\
657(15.9) \\
1854(14.7)\end{array}$ & $\begin{array}{l}{ }^{75} \mathrm{As}\left({ }^{3} \mathrm{He}, 2 n\right) \\
{ }^{77} \mathrm{Se}(p, 2 n)^{b}\end{array}$ & $\begin{array}{l}18 \rightarrow 10 \\
66 \rightarrow 14\end{array}$ & $\begin{array}{c}11 \\
1.3 \times 10^{3}\end{array}$ & $\begin{array}{c}{ }^{77} \mathrm{Br}(1.6) \\
{ }^{77} \mathrm{Br}(<15)\end{array}$ & $\begin{array}{l}{[105]} \\
{[108]}\end{array}$ \\
\hline${ }^{77} \mathrm{Kr}$ & $1.2 \mathrm{~h}$ & 84 & 2041 & $\begin{array}{l}130(80) \\
146(38)\end{array}$ & $\begin{array}{c}{ }^{77} \mathrm{Se}\left({ }^{3} \mathrm{He}, 3 n\right)^{b} \\
{ }^{79} \mathrm{Br}(p, 3 n)^{b}\end{array}$ & $\begin{array}{l}36 \rightarrow 15 \\
40 \rightarrow 30\end{array}$ & $\begin{array}{c}425 \\
7.4 \times 10^{3}\end{array}$ & $\begin{array}{l}{ }^{76,79} \mathrm{Kr}(0.7) \\
{ }^{79} \mathrm{Kr}(<1)\end{array}$ & $\begin{array}{l}{[109]} \\
{[110]}\end{array}$ \\
\hline${ }^{81} \mathrm{Rb}$ & $4.6 \mathrm{~h}$ & $27^{c}$ & 1026 & $\begin{array}{l}190(64.3) \\
446(23.3)\end{array}$ & ${ }^{82} \mathrm{Kr}(p, 2 n)^{b}$ & $27 \rightarrow 19$ & $1.8 \times 10^{3}$ & ${ }^{82 \mathrm{~m}} \mathrm{Rb}(7)$ & [111] \\
\hline${ }^{83} \mathrm{Sr}$ & $32.4 \mathrm{~h}$ & $26^{c}$ & 1254 & $\begin{array}{c}763(30) \\
381(19.6)\end{array}$ & $\begin{array}{c}{ }^{85} \mathrm{Rb}(p, 3 n)^{b} \\
{ }^{82} \mathrm{Kr}\left({ }^{3} \mathrm{He}, 2 n\right)^{b}\end{array}$ & $\begin{array}{l}37 \rightarrow 30 \\
18 \rightarrow 10\end{array}$ & $\begin{array}{c}160 \\
5\end{array}$ & $\begin{array}{l}{ }^{85} \mathrm{Sr}(0.2) \\
{ }^{82} \mathrm{Sr}(0.2)\end{array}$ & $\begin{array}{l}{[112]} \\
{[113]}\end{array}$ \\
\hline${ }^{86} \mathrm{Y}$ & $14.7 \mathrm{~h}$ & $33^{c}$ & 2019 & $\begin{array}{c}1077(82.5) \\
628(32.6) \\
1153(30.5)\end{array}$ & $\left.{ }^{88} \mathrm{Rr}(p, 3 n)^{3} \mathrm{He}, x n\right)$ & $\begin{array}{l}24 \rightarrow 12 \\
42 \rightarrow 30\end{array}$ & $\begin{array}{c}190 \\
1.0 \times 10^{3}\end{array}$ & $\begin{array}{l}{ }^{87} \mathrm{Y}(12) \\
{ }^{87} \mathrm{Y}(10.0)\end{array}$ & $\begin{array}{c}{[17]} \\
{[114,116]}\end{array}$ \\
\hline${ }^{89} \mathrm{Zr}$ & $78.4 \mathrm{~h}$ & 22.3 & 897 & $909(100)$ & ${ }^{\text {nat }} \operatorname{Sr}(\alpha, x)$ & $20 \rightarrow 8$ & 0.9 & ${ }^{88} \mathrm{Zr}(0.6)$ & [115] \\
\hline${ }^{94 \mathrm{~m}} \mathrm{Tc}$ & $52 \mathrm{~min}$ & 72.0 & 2470 & 871 (94.2) & $\begin{array}{c}{ }^{93} \mathrm{Nb}\left({ }^{3} \mathrm{He}, 2 n\right) \\
{ }_{92} \mathrm{Mo}(\alpha, d)^{b}\end{array}$ & $\begin{array}{l}18 \rightarrow 10 \\
26 \rightarrow 18\end{array}$ & $\begin{array}{l}33 \\
98\end{array}$ & $\begin{array}{l}{ }^{94 \mathrm{~g}} \mathrm{Tc}(25) \\
{ }^{94 \mathrm{~g}} \mathrm{Tc}(30)\end{array}$ & $\begin{array}{l}{[117]} \\
{[118]}\end{array}$ \\
\hline${ }^{110 g} \mathrm{In}$ & $1.1 \mathrm{~h}$ & $62^{c}$ & 2300 & $658(98)$ & $\begin{array}{c}{ }^{110} \mathrm{Cd}\left({ }^{3} \mathrm{He}, x\right)^{b} \\
{ }^{111} \mathrm{Cd}(p, 2 n)^{b}\end{array}$ & $\begin{array}{l}36 \rightarrow 25 \\
23 \rightarrow 16\end{array}$ & $\begin{array}{c}81 \\
6 \times 10^{3}\end{array}$ & $\begin{array}{c}{ }^{111 \mathrm{~g}} \operatorname{In}(<0.8) \\
{ }^{110 \mathrm{~m}} \operatorname{In}(10)\end{array}$ & $\begin{array}{l}{[119]} \\
{[120]}\end{array}$ \\
\hline${ }^{120 g} \mathrm{I}$ & $1.3 \mathrm{~h}$ & 56.0 & 4593 & $\begin{array}{c}560(73) \\
1522(11.2)\end{array}$ & ${ }^{122} \mathrm{Te}(p, 3 n)^{b}$ & $37 \rightarrow 32$ & $3.6 \times 10^{3}$ & ${ }^{120 m} \mathrm{I}(25)$ & {$[12]$} \\
\hline${ }^{124} \mathrm{I}$ & $4.18 \mathrm{~d}$ & 22.0 & $\begin{array}{c}2137 \\
1691(10.4) \\
723(10.0)\end{array}$ & $603(61)$ & $\begin{array}{l}{ }^{125} \mathrm{Te}(p, 2 n)^{b} \\
{ }^{123} \mathrm{Sb}(\alpha, 3 n)^{b}\end{array}$ & $\begin{array}{l}22 \rightarrow 15 \\
45 \rightarrow 30\end{array}$ & $\begin{array}{l}93 \\
16\end{array}$ & $\begin{array}{c}{ }^{125} \mathrm{I}(0.7) \\
{ }^{125,126} \mathrm{I}(2.5)\end{array}$ & $\begin{array}{l}{[121]} \\
{[122]}\end{array}$ \\
\hline
\end{tabular}

a: Decay data were mostly taken from ENSDF. For ${ }^{64} \mathrm{Cu},{ }^{76} \mathrm{Br},{ }^{120 g} \mathrm{I}$ and ${ }^{124} \mathrm{I}$ the $I_{\beta^{+}}$values were adopted from Refs. $[25,26]$.

b: Using highly enriched isotope as target material.

c: $I_{\beta^{+}}$value has rather large uncertainty.

${ }^{54} \mathrm{Fe}(d, n){ }^{55} \mathrm{Co},{ }^{86} \mathrm{Sr}(p, n){ }^{86} \mathrm{Y}$ and ${ }^{120} \mathrm{Te}(p, n){ }^{120 \mathrm{~g}} \mathrm{I}$ reactions, respectively, the level of the ${ }^{56} \mathrm{Co}$ impurity in ${ }^{55} \mathrm{Co}$, of ${ }^{87} \mathrm{Y}$ in ${ }^{86} \mathrm{Y}$ and of ${ }^{120 \mathrm{~m}} \mathrm{I}$ in ${ }^{120 \mathrm{~g}} \mathrm{I}$ is much higher. On the other hand, the production of the radionuclides ${ }^{52} \mathrm{Fe},{ }^{73} \mathrm{Se},{ }^{77} \mathrm{Kr}$ and ${ }^{83} \mathrm{Sr}$ demands a high intensity cyclotron, accelerating protons up to about $70 \mathrm{MeV}$ (in the case of ${ }^{52} \mathrm{Fe}$ preferably up to $100 \mathrm{MeV}$ ). Furthermore, the production of ${ }^{124} \mathrm{I}$ via the ${ }^{125} \mathrm{Te}(p, 2 n)$-reaction deserves more attention. The ${ }^{125} \mathrm{I}-$ impurity level of $0.7 \%$ in this process [121] is higher than that of $<0.1 \%$ in the ${ }^{124} \mathrm{Te}(p, n)$-process [19], but the yield of ${ }^{124} \mathrm{I}$ is by a factor of about six higher. Thus more efforts need to be invested in intermediate energy reactions to make better use of production possibilities of some novel positron emitters.

\subsection{Production of novel parent generator radionuclides}

Two standard positron emitters, namely ${ }^{68} \mathrm{Ga}\left(T_{1 / 2}=68 \mathrm{~min}\right)$ and ${ }^{82} \mathrm{Rb}\left(T_{1 / 2}=1.3 \mathrm{~min}\right)$ are routinely available via the generator systems ${ }^{68} \mathrm{Ge}(271 \mathrm{~d}) /{ }^{68} \mathrm{Ga}$ and ${ }^{82} \mathrm{Sr}(25.3 \mathrm{~d}) /{ }^{82} \mathrm{Rb}$ (see Introduction). For production of the parent radionuclide, a high intensity intermediate energy accelerator is needed. Presently the supply of both ${ }^{68} \mathrm{Ge}$ and ${ }^{82} \mathrm{Sr}$ appears to be adequate. However, due to enhancing interest in ${ }^{68} \mathrm{Ga}$-radiopharmaceuticals, more efforts related to ${ }^{68} \mathrm{Ge}$ production and an efficient generator column preparation may soon be called for. Furthermore, since the half-life of ${ }^{68} \mathrm{Ga}$ is not very short, its direct pro- 
Table 3. Production of novel positron emitters via generator systems.

\begin{tabular}{|c|c|c|c|c|c|c|c|c|c|}
\hline \multirow{2}{*}{$\begin{array}{l}\text { Parent } \\
\text { nuclide } \\
\left(T_{1 / 2}\right)\end{array}$} & \multicolumn{5}{|c|}{ Decay data of daughter } & \multirow{2}{*}{$\begin{array}{c}\text { Production } \\
\text { method of } \\
\text { parent }\end{array}$} & \multirow{2}{*}{$\begin{array}{l}\text { Energy } \\
\text { range } \\
{[\mathrm{MeV}]}\end{array}$} & \multirow{2}{*}{$\begin{array}{l}\text { Theor. yield } \\
\text { of parent } \\
{[\mathrm{MBq} / \mu \mathrm{Ah}]}\end{array}$} & \multirow[t]{2}{*}{ Reference } \\
\hline & Nuclide & $T_{1 / 2}$ & $\begin{array}{l}I_{\beta}+ \\
{[\%]}\end{array}$ & $\begin{array}{l}E_{\max \beta^{+}} \\
{[\mathrm{keV}]}\end{array}$ & $\begin{array}{c}E_{\gamma} \\
{[\operatorname{keV}(\%)]}\end{array}$ & & & & \\
\hline${ }^{44} \mathrm{Ti}(60.4 \mathrm{a})$ & ${ }^{44} \mathrm{Sc}$ & $3.9 \mathrm{~h}$ & 94.3 & 1474 & 1157 (99.9) & ${ }^{45} \mathrm{Sc}(p, 2 n)$ & $32 \rightarrow 18$ & $\sim 3 \times 10^{3}$ & {$[141]$} \\
\hline${ }^{52} \mathrm{Fe}(8.3 \mathrm{~h})$ & ${ }^{52 \mathrm{~m}} \mathrm{Mn}$ & $21 \mathrm{~min}$ & 95.0 & 2633 & $1434(98.2)$ & $\begin{array}{c}{ }^{55} \mathrm{Mn}(p, 4 n) \\
{ }^{52} \mathrm{Cr}\left({ }^{3} \mathrm{He}, 3 n\right)\end{array}$ & $\begin{aligned} 100 & \rightarrow 60 \\
36 & \rightarrow 17\end{aligned}$ & $\begin{array}{l}22 \\
1.3\end{array}$ & $\begin{array}{l}{[97]} \\
{[96]}\end{array}$ \\
\hline${ }^{62} \mathrm{Zn}(9.1 \mathrm{~h})$ & ${ }^{62} \mathrm{Cu}$ & $9.7 \mathrm{~min}$ & 97.4 & 2926 & $1173(0.34)$ & $\begin{array}{c}{ }^{\mathrm{nat}} \mathrm{Cu}(p, x n) \\
{ }^{\mathrm{nat}} \mathrm{Zn}(p, x)\end{array}$ & $\begin{array}{l}30 \rightarrow 18 \\
70 \rightarrow 30\end{array}$ & $\begin{array}{l}230 \\
700\end{array}$ & [133] \\
\hline${ }^{72} \mathrm{Se}(8.5 \mathrm{~d})$ & ${ }^{72} \mathrm{As}$ & $26.0 \mathrm{~h}$ & 87.8 & 3334 & $834(79.5)$ & $\begin{array}{l}{ }^{75} \mathrm{As}(p, 4 n) \\
{ }^{75} \mathrm{As}(d, 5 n) \\
{ }^{\mathrm{nat}} \mathrm{Ge}\left({ }^{3} \mathrm{He}, x n\right)\end{array}$ & $\begin{array}{l}45 \rightarrow 35^{a} \\
55 \rightarrow 40 \\
36 \rightarrow 10\end{array}$ & $\begin{array}{c}8 \\
7 \\
0.7\end{array}$ & $\begin{array}{l}{[102]} \\
{[102]}\end{array}$ \\
\hline${ }^{122} \mathrm{Xe}(20.1 \mathrm{~h})$ & ${ }^{122} \mathrm{I}$ & $3.6 \mathrm{~min}$ & 77.0 & 3100 & $564(18)$ & $\begin{array}{l}{ }^{127} \mathrm{I}(p, 6 n) \\
{ }^{124} \mathrm{Xe}(p, 3 n)\end{array}$ & $\begin{array}{l}36 \rightarrow 10 \\
65 \rightarrow 43 \\
43 \rightarrow 35\end{array}$ & $\begin{array}{l}0.1 \\
230 \\
500\end{array}$ & $\begin{array}{l}{[103]} \\
{[135]} \\
{[136]}\end{array}$ \\
\hline${ }^{140} \mathrm{Nd}(3.4 \mathrm{~d})$ & ${ }^{140} \mathrm{Pr}$ & $3.4 \mathrm{~min}$ & 51.0 & 2366 & $1596(0.5)$ & $\begin{array}{c}{ }^{141} \operatorname{Pr}(p, 2 n) \\
{ }^{\mathrm{nat}} \mathrm{Ce}\left({ }^{3} \mathrm{He}, x n\right)\end{array}$ & $\begin{array}{l}30 \rightarrow 15 \\
35 \rightarrow 20\end{array}$ & $\begin{array}{c}210 \\
12\end{array}$ & $\begin{array}{l}{[139]} \\
{[139]}\end{array}$ \\
\hline
\end{tabular}

a: The production process was investigated only up to $45 \mathrm{MeV}$.

duction via the ${ }^{68} \mathrm{Zn}(p, n)$-reaction is also gaining some importance.

Some other generator systems have also been proposed (for a review of production routes $c f$. [131, 132]). A few interesting systems for furnishing some novel positron emitters are listed in Table 3. They are discussed in some detail below. The systems ${ }^{52} \mathrm{Fe} /{ }^{52 \mathrm{~m}} \mathrm{Mn},{ }^{62} \mathrm{Zn} /{ }^{62} \mathrm{Cu}$ and ${ }^{122} \mathrm{Xe} /{ }^{122} \mathrm{I}$ were proposed rather long time ago. Out of those, more detailed studies have been carried out only on the system ${ }^{62} \mathrm{Zn} /{ }^{62} \mathrm{Cu}$. In general not much progress has been reported regarding their further applications. This is mainly due to the short half-lives of the parents, combined with the difficulties in their production. Although the ${ }^{62} \mathrm{Zn}$ parent nuclide can be produced with $30 \mathrm{MeV}$ protons [ $c f$. 133], the production of ${ }^{52} \mathrm{Fe}$ and ${ }^{122} \mathrm{Xe}$ demands higher energies $[97,135,136]$. Another reason for the limited use of those systems is the relatively short half-life of the daughter positron emitter.

The generator systems ${ }^{72} \mathrm{Se} /{ }^{72} \mathrm{As}$ and ${ }^{140} \mathrm{Nd} /{ }^{140} \mathrm{Pr}$ have great potential, the former for studying the biological behaviour of arsenic and the latter as an in vivo generator, if the Auger electron emitter ${ }^{140} \mathrm{Nd}$ is used in endoradiotherapy. The yield of the parent radionuclide ${ }^{72} \mathrm{Se}$ is rather low [ $c f .102,103]$. Nonetheless two generator systems for obtaining the daughter ${ }^{72} \mathrm{As}$, one based on distillation [137] and the other one on solid phase extraction [138] have been developed. With regard to ${ }^{140} \mathrm{Nd}$, the $(p, 2 n)$ and $\left({ }^{3} \mathrm{He}, x n\right)$ reactions on ${ }^{141} \mathrm{Pr}$ and ${ }^{\text {nat }} \mathrm{Ce}$, respectively, have been investigated in detail [ $c f .139]$. As expected, the former reaction leads to a much higher yield. A generator system based on physico-chemical transitions in ${ }^{140} \mathrm{Pr}$ complexes has also been described $[c f .140]$.

The generator system ${ }^{44} \mathrm{Ti} /{ }^{44} \mathrm{Sc}$ has received some attention in recent years. Due to the long half-life of 60.4 years of the parent, it is rather difficult to produce. Furthermore, there may be some regulatory problems in the introduction of this very long-lived system. Nonetheless, from the scientific and application point of view (see below), it appears worthwhile to develop it further. The suggested production reaction is ${ }^{45} \mathrm{Sc}(p, 2 n){ }^{44} \mathrm{Ti}$ and the excitation function, recently measured [141], is reproduced in Fig. 8. Evidently the cross section is not very high, which is qualitatively understandable, because the emission of two

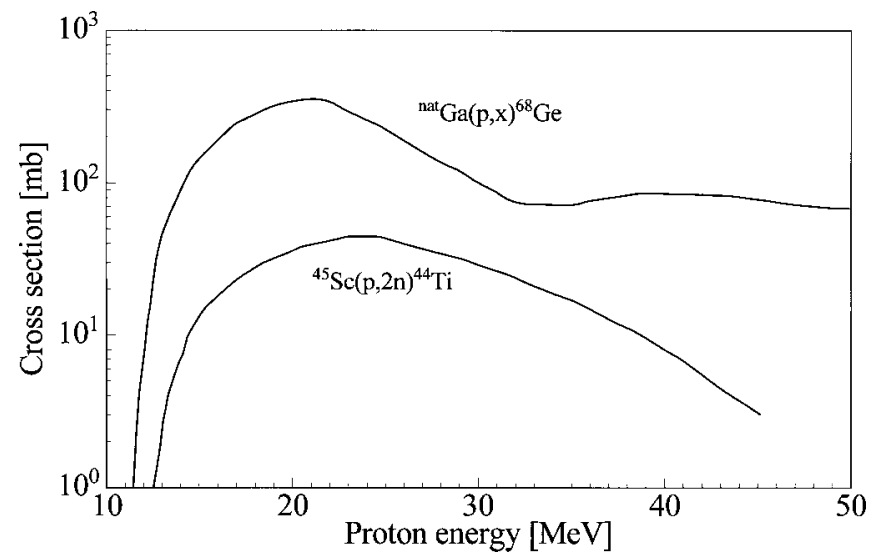

Fig. 8. Comparison of excitation functions of the nuclear reactions ${ }^{45} \mathrm{Sc}(p, 2 n){ }^{44} \mathrm{Ti}$ and ${ }^{\text {nat }} \mathrm{Ga}(p, x n){ }^{68} \mathrm{Ge}$ used to induce the parent activities for preparation of the radionuclide generator systems ${ }^{44} \mathrm{Ti} /{ }^{44} \mathrm{Sc}$ and ${ }^{68} \mathrm{Ge} /{ }^{68} \mathrm{Ga}$. The data for the former reaction are reproduced from Ref. [141] and those for the latter from Ref. [142].

neutrons in the interaction of a proton with a relatively light mass nucleus, such as ${ }^{45} \mathrm{Sc}$, is not very favoured. For comparison the excitation function of the nat $\mathrm{Ga}(p, x n){ }^{68} \mathrm{Ge}$ reaction $[c f .142]$ is also shown in Fig. 8. The first peak at about $21 \mathrm{MeV}$ is attributed to the ${ }^{69} \mathrm{Ga}(p, 2 n)^{68} \mathrm{Ge}$ reaction and the second increase beyond $35 \mathrm{MeV}$ is due to the contribution from the ${ }^{71} \mathrm{Ga}(p, 4 n)^{68} \mathrm{Ge}$ process. The excitation function for the formation of ${ }^{68} \mathrm{Ge}$ has a slightly lower threshold and an order of magnitude higher cross section than the ${ }^{45} \operatorname{Sc}(p, 2 n)^{44} \mathrm{Ti}$ reaction. Thus there is little analogy between the two reactions. The production of ${ }^{68} \mathrm{Ge}$ is routinely done. In the case of ${ }^{44} \mathrm{Ti}$, to date a $185 \mathrm{MBq}$ generator has been reported [143] and some post-elution purification of ${ }^{44} \mathrm{Sc}$ has been described [144]. Higher current targetry and long irradiation periods will be called for to obtain higher yields.

\section{Applications of novel positron emitters}

The applications of novel positron emitters are manifold $[c f .4]$. A detailed discussion is beyond the scope of this 
article; therefore, only the three major areas of application are briefly mentioned.

1. Study of slow metabolic processes, e.g. protein synthesis, cell proliferation, etc..

2. Quantification of SPECT-radiopharmaceuticals.

3. Quantification of targeted therapy.

Some of the important positron emitters under the first category are ${ }^{52} \mathrm{Fe}\left(T_{1 / 2}=8.3 \mathrm{~h}\right),{ }^{55} \mathrm{Co}\left(T_{1 / 2}=17.6 \mathrm{~h}\right),{ }^{72} \mathrm{As}$ $\left(T_{1 / 2}=26.0 \mathrm{~h}\right),{ }^{73} \mathrm{Se}\left(T_{1 / 2}=7.1 \mathrm{~h}\right)$, and ${ }^{124} \mathrm{I}\left(T_{1 / 2}=4.18 \mathrm{~d}\right)$. When attached to proper organic compounds, they could be used for detection of tumor, neuronal damage or organ functional deficiency. The slow uptake kinetics by an organ can be conveniently and quantitatively followed using a longer lived positron emitter and positron emission tomography.

With regard to quantification of SPECT-radiopharmaceuticals, an analogue approach is needed, which involves the use of a positron emitting nuclide of the chemical element of the SPECT radionuclide. Thus for quantification of a ${ }^{99 \mathrm{~m}} \mathrm{Tc}$-radiopharmaceutical, labelling can be done using the positron emitting radionuclide ${ }^{94 \mathrm{~m}} \mathrm{Tc}\left(T_{1 / 2}=52 \mathrm{~min}\right)$ followed by a PET measurement. This way the ${ }^{99 \mathrm{~m}} \mathrm{Tc}$-based SPECT flow agent terboroxime (CardioTec) was labelled with ${ }^{94 \mathrm{~m}} \mathrm{Tc}$ for quantitative PET investigation [cf. 145], Similarly, ${ }^{94 \mathrm{~m}} \mathrm{Tc}$ has been applied in studies related to changes in dopamine transporter concentrations (e.g. with TRODAT1) $[146]$.

A very significant application of non-standard longer lived positron emitters is in therapy planning. Since dosimetry in endotherapy with purely $\beta^{-}$emitting radionuclides like ${ }^{90} \mathrm{Y}\left(T_{1 / 2}=2.7 \mathrm{~d}\right)$ has a rather large uncertainty, a mixture of the $\beta^{+}$emitting ${ }^{86} \mathrm{Y}\left(T_{1 / 2}=14.7 \mathrm{~h}\right)$ and the therapeutic radionuclide ${ }^{90} \mathrm{Y}$ was used [147]. The uptake kinetics were determined by PET imaging of ${ }^{86} \mathrm{Y}$, and the results were used in an accurate dosimetric calculation. This concept is now finding increasing application. Another radionuclide investigated is ${ }^{83} \mathrm{Sr}\left(T_{1 / 2}=32.2 \mathrm{~h}\right)$ which can be combined with the purely $\beta^{-}$emitting therapeutic radionuclide ${ }^{89} \mathrm{Sr}\left(T_{1 / 2}=50.0 \mathrm{~d}\right)$. The dosimetry in the case of the most commonly used therapeutic radionuclide ${ }^{131} \mathrm{I}\left(T_{1 / 2}=8.0 \mathrm{~d}\right)$ is fairly well established. However, if a PET study using ${ }^{124}$ I precedes the use of ${ }^{131} \mathrm{I}$, the dosimetric calculations can be done even more precisely. A further advantage of ${ }^{124} \mathrm{I}$ is that it could itself be used as a therapeutic agent. Because of the combination of PET and endoradiotherapy, allowing precise dosimetry, this radionuclide is superior to the commonly used reactor radionuclide ${ }^{131} \mathrm{I}$. The cost of ${ }^{124} \mathrm{I}$, however, is higher than that of ${ }^{131} \mathrm{I}$.

In recent years, the importance of metallic positron emitters in quantification of radioimmunotherapy has been increasing. Radionuclides such as ${ }^{67} \mathrm{Cu}\left(T_{1 / 2}=2.6 \mathrm{~d}\right),{ }^{67} \mathrm{Ga}$ $\left(T_{1 / 2}=3.3 \mathrm{~d}\right)$ and ${ }^{111} \mathrm{In}\left(T_{1 / 2}=2.8 \mathrm{~d}\right)$ can be attached to monoclonal antibodies (mAB) leading to therapeutic effects through interactions of $\beta^{-}$particles or Auger electrons with the tissue. The use of the respective positron emitting radionuclides ${ }^{64} \mathrm{Cu}\left(T_{1 / 2}=12.7 \mathrm{~h}\right),{ }^{68} \mathrm{Ga}\left(T_{1 / 2}=67.6 \mathrm{~min}\right)$ and ${ }^{110 g}$ In $\left(T_{1 / 2}=1.1 \mathrm{~h}\right)$ allows PET imaging for quantification purposes. In particular, the radionuclide ${ }^{64} \mathrm{Cu}$ (with multiple decay mode) has proved to be very suitable for combining PET imaging and targeted therapy [cf. 148].

\section{Conclusions and perspectives}

Radionuclide production technology at cyclotrons has been well developed, especially for short-lived organic positron emitters. In this regard, all components of the technology, i.e., special purpose cyclotron, high current irradiation target and automated or remotely controlled chemical processing unit can now be commercially purchased. Furthermore, two radionuclide generator systems providing short-lived positron emitters $\left({ }^{68} \mathrm{Ga}\right.$ and $\left.{ }^{82} \mathrm{Rb}\right)$ are supplied by several companies, though the parent nuclides are produced through intermediate energy nuclear reactions only at a few large research centres.

In contrast to the commonly used positron emitters, a few other longer lived positron emitting radionuclides, having passed the stage of laboratory scale production and clinical evaluation, are now in great demand, but are not easily available. A few examples are ${ }^{64} \mathrm{Cu},{ }^{86} \mathrm{Y}$ and ${ }^{124} \mathrm{I}$. They are produced using highly enriched target material but low energy cyclotrons, whereby the radionuclidic purity is high but the yield is low. Efforts are therefore underway in commercially oriented laboratories to increase the production yields of those radionuclides and thus to ensure their availability on a broader scale.

The number of positron emitters potentially interesting for medical applications is relatively large. They are research type radionuclides and the development work needed is rather heavy, calling for investigations in many directions, starting from nuclear data measurements, proceeding through high current target construction and chemical processing, and leading up to quality control of the final product. Similar to the three novel positron emitters mentioned above, in many cases a combination of isotopically enriched target material and a small-sized cyclotron may be sufficient for production. However, for production of many new nuclides high intensity intermediate energy cyclotrons have great potential. This appears to be particularly true for metallic positron emitters used in combination with a longer lived $\beta^{-}$emitter or Auger electron emitter for radioimmunotherapy. The four pairs, namely ${ }^{44} \mathrm{Sc} /{ }^{47} \mathrm{Sc},{ }^{64} \mathrm{Cu} /{ }^{67} \mathrm{Cu}$, ${ }^{68} \mathrm{Ga} /{ }^{67} \mathrm{Ga}$ and ${ }^{110 g} \mathrm{In} /{ }^{111} \mathrm{In}$, could be developed further with the availability of a new generation high power accelerator having proton energies up to $100 \mathrm{MeV}$. In general it is concluded that the field of cyclotron production of medical radionuclides is flourishing and that many new impulses are expected within the next few years, especially with regard to the use of novel positron emitters and therapeutic radionuclides.

Acknowledgment. This article summarizes research and development work on novel positron emitters carried out over many years. The author is grateful to his research group for painstaking efforts as well as to Prof. G. Stöcklin and Prof. H. H. Coenen, the former and present directors of the Institute of Nuclear Chemistry of the Research Centre Jülich, for their continuous support and encouragement.

\section{References}

1. Stöcklin, G., Qaim, S. M., Rösch, F.: The impact of radioactivity on medicine. Radiochim. Acta 70/71, 249-272 (1995).

2. Qaim, S. M., Clark, J. C., Crouzel, C., Guillaume, M., Helmeke, H. J., Nebeling, B., Pike, V. W., Stöcklin, G.: PET radionuclide production. In: Radiopharmaceuticals for Positron Emission To- 
mography - Methodological Aspects. (Stöcklin, G., Pike, V. W., eds.) Kluwer, Dordrecht, The Netherlands (1993), pp. 1-43.

3. Qaim, S. M.: Cyclotron production of medical radionuclides. In: Handbook of Nuclear Chemistry. Vol. 4 (Rösch, F., ed.) Kluwer, Dordrecht, The Netherlands (2003), pp. 47-79.

4. Proceedings of the Workshop on Non-standard Positron Emitters, Aachen (2007), Special Issue of the Quart. J. Nucl. Med. Mol. Imaging 52, 101-206 (2008).

5. Pagani, M., Stone-Elander, S., Larsson, S. A.: Alternative positron emission tomography with non-conventional positron emitters: effects of their physical properties on image quality and potential clinical applications. Eur. J. Nucl. Med. 24, 1301-1327 (1997).

6. Nickles, R. J.: The production of a broader palette of PET tracers. J. Label. Compd. Radiopharm. 46, 1-27 (2003).

7. McQuade, P., Rowland, D. J., Lewis, J. S., Welch, M. J.: Positron emitting isotopes produced on biomedical cyclotrons. Curr. Med. Chem. 12, 807-818 (2005).

8. Qaim, S. M.: Decay data and production yields of some nonstandard positron emitters used in positron emission tomography. Quart. J. Nucl. Med. Mol. Imaging 52, 111-120 (2008).

9. Qaim, S. M.: Nuclear data relevant to cyclotron produced shortlived medical radioisotopes. Radiochim. Acta 30, 147-162 (1982).

10. Qaim, S. M.: Nuclear data relevant to the production and application of diagnostic radionuclides. Radiochim. Acta 89, 223-232 (2001).

11. Qaim, S. M., Sudár, S., Fessler, A.: Influence of reaction channel on the isomeric cross-section ratio. Radiochim. Acta 93, 503-506 (2005).

12. Hohn, A., Scholten, B., Coenen, H. H., Qaim, S. M.: Excitation functions of $(p, x n)$-reactions on highly enriched ${ }^{122} \mathrm{Te}$ : relevance to the production of ${ }^{120 g} \mathrm{I}$. Appl. Radiat. Isot. 49, 93-98 (1998).

13. Hohn, A., Coenen, H. H., Qaim, S. M.: Nuclear data relevant to the production of ${ }^{120 \mathrm{I}} \mathrm{I}$ via the ${ }^{120} \mathrm{Te}(p, n)$-process at a small-sized cyclotron. Appl. Radiat. Isot. 49, 1493-1496 (1998).

14. Szelecsényi, F., Blessing, G., Qaim, S. M.: Excitation functions of proton induced nuclear reactions on enriched ${ }^{61} \mathrm{Ni}$ and ${ }^{64} \mathrm{Ni}$ : possibility of production of no-carrier-added ${ }^{61} \mathrm{Cu}$ and ${ }^{64} \mathrm{Cu}$ at a small cyclotron. Appl. Radiat. Isot. 44, 575-580 (1993).

15. Hassan, H. E., Qaim, S. M., Shubin, Yu., Azzam, A., Morsy, M., Coenen, H. H.: Experimental studies and nuclear model calculations on proton induced reactions on ${ }^{\text {nat }} \mathrm{Se},{ }^{76} \mathrm{Se}$ and ${ }^{77} \mathrm{Se}$ with particular reference to the production of the medically interesting radionuclides ${ }^{76} \mathrm{Br}$ and ${ }^{77} \mathrm{Br}$. Appl. Radiat. Isot. 60, 899-909 (2004).

16. Kovács, Z., Tárkányi, F., Qaim, S. M., Stöcklin, G.: Production of $6.5 \mathrm{~h}{ }^{82 \mathrm{~m}} \mathrm{Rb}$ via the ${ }^{82} \mathrm{Kr}(p, n)$-process at a low-energy cyclotron - a potential substitute for ${ }^{82} \mathrm{Rb}$. Appl. Radiat. Isot. 42, 831-834 (1991).

17. Rösch, F., Qaim, S. M., Stöcklin, G.: Nuclear data relevant to the production of the positron emitting radioisotope ${ }^{86} \mathrm{Y}$ via the ${ }^{86} \mathrm{Sr}(p, n)$ - and ${ }^{\text {nat }} \mathrm{Rb}\left({ }^{3} \mathrm{He}, x n\right)$-processes. Radiochim. Acta 61, 18 (1993).

18. Rösch, F., Qaim, S. M.: Nuclear data relevant to the production of the positron emitting technetium isotope ${ }^{94 \mathrm{~m}} \mathrm{Tc}$ via the ${ }^{94} \operatorname{Mo}(p, n)$-reaction. Radiochim. Acta 62, 115-121 (1993); Erratum 75, 227 (1996).

19. Scholten, B., Kovács, Z., Tárkányi, F., Qaim, S. M.: Excitation functions of ${ }^{124} \mathrm{Te}(p, x n)^{124,123} \mathrm{I}$ reactions from 6 to $31 \mathrm{MeV}$ with special reference to the production of ${ }^{124} \mathrm{I}$ at a small cyclotron. Appl. Radiat. Isot. 46, 255-259 (1995).

20. Qaim, S. M.: Radiochemical determination of nuclear data for theory and applications. J. Radioanal. Nucl. Chem. 284, 489-505 (2010).

21. Aslam, M. N., Sudár, S., Hussain, M., Malik, A. A., Shah, H. A., Qaim, S. M.: Charged particle induced reaction cross section data for production of the emerging medically important positron emitter ${ }^{64} \mathrm{Cu}$ : a comprehensive evaluation. Radiochim. Acta 97, 669686 (2009).

22. Aslam, M. N., Sudár, S., Hussain, M., Malik, A. A., Shah, H. A., Qaim, S. M.: Evaluation of excitation functions of proton and deuteron induced reactions on enriched tellurium isotopes with special relevance to the production of iodine-124. Appl. Radiat. Isot. 68, 1760-1773 (2010).
23. Tárkányi, F., Takács, S., Király, B., Szelecsényi, F., Andó, L., Bergman, J., Heselius, S. J., Solin, O., Hermanne, A., Shubin, Yu.N., Ignatyuk, A.: Excitation functions of ${ }^{3} \mathrm{He}$ - and $\alpha$-particle induced nuclear reactions on ${ }^{\text {nat }} \mathrm{Sb}$ for production of medically relevant ${ }^{123} \mathrm{I}$ and ${ }^{124} \mathrm{I}$ radioisotopes. Appl. Radiat. Isot. 67, 10011006 (2009).

24. Aslam, M. N., Sudár, S., Hussain, M., Malik, A. A., Qaim, S. M.: Evaluation of excitation functions of ${ }^{3} \mathrm{He}$ - and $\alpha$-particle induced reactions on antimony isotopes with special relevance to the production of iodine-124. Appl. Radiat. Isot. 69, 94-104 (2011).

25. Hohn, A., Coenen, H. H., Qaim, S. M.: Positron emission intensity in the decay of ${ }^{120 \mathrm{~g}}$ I. Radiochim. Acta 88, 139-141 (2000).

26. Qaim, S. M., Bisinger, T., Hilgers, K., Nayak, D., Coenen, H. H.: Positron emission intensities in the decay of ${ }^{64} \mathrm{Cu},{ }^{76} \mathrm{Br}$ and ${ }^{124} \mathrm{I}$. Radiochim. Acta 95, 67-73 (2007).

27. Qaim, S. M.: Target development for medical radioisotope production at a cyclotron. Nucl. Instrum. Methods A 282, 289-295 (1989).

28. Spellerberg, S., Reimer, P., Blessing, G., Coenen, H. H., Qaim, S. M.: Production of ${ }^{55} \mathrm{Co}$ and ${ }^{57} \mathrm{Co}$ via proton induced reactions on highly enriched ${ }^{58} \mathrm{Ni}$. Appl. Radiat. Isot. 49, 1519-1522 (1998).

29. Blessing, G., Tárkányi, F., S.M. Qaim, S. M.: Production of ${ }^{82 \mathrm{~m}} \mathrm{Rb}$ via the ${ }^{82} \mathrm{Kr}(p, n)$-process on highly enriched ${ }^{82} \mathrm{Kr}$ : a remotely controlled compact system for irradiation, safe handling and recovery of the target gas and isolation of the radioactive product. Appl. Radiat. Isot. 48, 37-43 (1997).

30. Qaim, S. M., Hohn, A., Bastian, Th., El-Azoney, K. M., Blessing, G., Spellerberg, S., Scholten, B., Coenen, H. H.: Some optimisation studies relevant to the production of high-purity ${ }^{124} \mathrm{I}$ and ${ }^{120 g} \mathrm{I}$ at a small-sized cyclotron. Appl. Radiat. Isot. 58, 69-78 (2003).

31. Blessing, G., Lavi, N., Qaim, S. M.: Production of ${ }^{73}$ Se via the ${ }^{70} \mathrm{Ge}(\alpha, n)$-process using high current target materials. Appl. Radiat. Isot. 43, 455-461 (1992).

32. Blessing, G., Lavi, N., Hashimoto, K., Qaim, S. M.: Thermochromatographic separation of radioselenium from irradiated $\mathrm{Cu}_{3} \mathrm{As}-$ target: production of no-carrier added ${ }^{75} \mathrm{Se}$. Radiochim. Acta $\mathbf{6 5}$, 93-98 (1994).

33. Blessing, G., Weinreich, R., Qaim, S. M., Stöcklin, G.: Production of ${ }^{75} \mathrm{Br}$ and ${ }^{77} \mathrm{Br}$ via the $\left.{ }^{75} \mathrm{As}\left({ }^{3} \mathrm{He}, 3 n\right)\right)^{75} \mathrm{Br}$ and ${ }^{75} \mathrm{As}(\alpha, 2 n){ }^{77} \mathrm{Br}$ reactions using $\mathrm{Cu}_{3} \mathrm{As}$-alloy as a high-current target material. Int. J. Appl. Radiat. Isot. 33, 333-339 (1982).

34. Tolmachev, V., Lövqvist, A., Einarsson, L., Schultz, J., Lundqvist, H.: Production of ${ }^{76} \mathrm{Br}$ by a low-energy cyclotron. Appl. Radiat. Isot. 49, 1537-1540 (1998).

35. Rösch, F., Novgorodov, A. F., Qaim, S. M.: Thermochromatographic separation of ${ }^{94 \mathrm{~m}} \mathrm{Tc}$ from enriched molybdenum targets and its large scale production for nuclear medical application. Radiochim. Acta 64, 113-120 (1994).

36. Rösch, F., Qaim, S. M., Stöcklin, G.: Production of the positron emitting radioisotope ${ }^{86} \mathrm{Y}$ for nuclear medical application. Appl. Radiat. Isot. 44, 677-681 (1993).

37. Kettern, K., Linse, K.-H., Spellerberg, S., Coenen, H. H., Qaim, S. M.: Radiochemical studies relevant to the production of ${ }^{86} \mathrm{Y}$ and ${ }^{88} \mathrm{Y}$ at a small-sized cyclotron. Radiochim. Acta 90, 845-849 (2002).

38. Lubberink, M., $\quad$ Lundqvist, H., $\quad$ Westlin, J. E., Tolmachev, V., Schneider, H., Lövqvist, A., Sundin, A., Carlsson, J.: Positron emission tomography and radioimmunotargeting: aspects of quantification and dosimetry. Acta Oncol. 38, 343-349 (1999).

39. Lubberink, M., Tolmachev, V., Beshara, S., Lundqvist, H.: Quantification aspects of patient studies with ${ }^{52} \mathrm{Fe}$ in positron emission tomography. Appl. Radiat. Isot. 51, 707-715 (1999).

40. Ribeiro, M. J., Almeida, P., Strul, D., Ferreira, N., Loch, C., Brulon, V., Trébossen, R., Maziére, B., Bendriem, B.: Comparison of fluorine-18 and bromine-76 imaging in positron emission tomography. Eur. J. Nucl. Med. 26, 758-766 (1999).

41. Herzog, H., Tellmann, L., Qaim, S. M., Spellerberg, S., Schmid, A., Coenen, H. H.: PET quantitation and imaging of the non-pure positron emitting iodine isotope ${ }^{124} \mathrm{I}$. Appl. Radiat. Isot. 56, 673679 (2002).

42. Herzog, H., Qaim, S. M., Tellmann, L., Spellerberg, S., Kruecker, D., Coenen, H. H.: Assessment of the short-lived non-pure 
positron emitting nuclide ${ }^{120}$ I for PET imaging. Eur. J. Nucl. Med. Mol. Imaging 33, 1249-1257 (2006).

43. Laforest, R., Liu, X.: Image quality with non-standard nuclides in PET. Quart. J. Nucl. Med. Mol. Imaging 52, 151-158 (2008).

44. Herzog, H., Tellmann, L., Scholten, B., Coenen, H. H., Qaim, S. M.: PET imaging problems with the non-standard positron emitters yttrium-86 and iodine-124. Quart. J. Nucl. Med. Mol. Imaging 52, 159-165 (2008).

45. McCarthy, D. W., Shefer, R. E., Klinkowstein, R. E., Bass, L. A., Margeneau, W. H., Cutler, C. S., Anderson, C. J., Welch, M. J.: Efficient production of high specific activity ${ }^{64} \mathrm{Cu}$ using a biomedical cyclotron. Nucl. Med. Biol. 24, 35-43 (1997).

46. Szajek, L. P., Meyer, W., Plascjak, P., Eckelman, W. C.: Semiremote production of $\left[{ }^{64} \mathrm{Cu}\right] \mathrm{CuCl}_{2}$ and preparation of high specific activity $\left.{ }^{[64} \mathrm{Cu}\right] \mathrm{Cu}$-ATSM for PET studies. Radiochim. Acta 93, 239-244 (2005).

47. Obata, A., Kasamatsu, S., McCarthy, D. W., Welch, M. J., Saji, H., Yonekura, Y., Fujibayashi, Y.: Production of therapeutic quantities of ${ }^{64} \mathrm{Cu}$ using a $12 \mathrm{MeV}$ cyclotron. Nucl. Med. Biol. 30, 535-539 (2003).

48. Avila-Rodriguez, M. A., Nye, J. A., Nickles, R. J.: Simultaneaus production of high specific activity ${ }^{64} \mathrm{Cu}$ and ${ }^{61} \mathrm{Co}$ with $11.4 \mathrm{MeV}$ protons on enriched ${ }^{64} \mathrm{Ni}$ nuclei. Appl. Radiat. Isot. 65, 11151120 (2007).

49. Sadeghi, M., Amiri, M., Roshanfarzad, P., Avila, M., Tenreiro, C.: Radiochemical studies relevant to the no-carrier-added production of ${ }^{61,64} \mathrm{Cu}$ at a cyclotron. Radiochim. Acta 96, 399-402 (2008).

50. Le, V. S., Howse, J., Zaw, M., Pellegrini, P., Katsifis, A., Greguric, I., Weiner, R.: Alternative method for ${ }^{64} \mathrm{Cu}$ radioisotope production. Appl. Radiat. Isot. 67, 1324-1331 (2009).

51. Abbas, K., Kozempel, J., Bonardi, M., Groppi, F., Alfarano, A., Holzwarth, U., Simonelli, F., Hofmann, H., Horstmann, W., Menapace, E., Lešetický, L., Gibson, N.: Cyclotron production of ${ }^{64} \mathrm{Cu}$ by deuteron irradiation of ${ }^{64} \mathrm{Zn}$. Appl. Radiat. Isot. 64, 1001-1005 (2006).

52. Kozempel, J., Abbas, K., Simonelli, F., Zampese, M., Holzwarth, U., Gibson, N., Lešetický, L.: A novel method for n.c.a. ${ }^{64} \mathrm{Cu}$ production by the ${ }^{64} \mathrm{Zn}(d, 2 p){ }^{64} \mathrm{Cu}$ reaction and dual ion-exchange column chromatography. Radiochim. Acta 95, 75-80 (2007).

53. Lambrecht, R. M., Sajjad, M., Qureshi, M. A., Al-Yanbawi, S. J.: Production of iodine-124. J. Radioanal. Nucl. Chem. Lett. 127, 143-150 (1988).

54. Bastian, Th., Coenen, H. H., Qaim, S. M.: Excitation functions of ${ }^{124} \mathrm{Te}(d, x n)^{124,125} \mathrm{I}$ reactions from threshold up to $14 \mathrm{MeV}$ : comparative evaluation of nuclear routes for the production of ${ }^{124} \mathrm{I}$. Appl. Radiat. Isot. 55, 303 - 308 (2001).

55. Sheh, Y., Koziorowski, J., Balatoni, J., Lom, C., Dahl, J. R., Finn, R. D.,: Low energy cyclotron production and chemical separation of no carrier added iodione-124 from a usable, enriched tellurium-124 dioxide/aluminium oxide solid solution target. Radiochim. Acta 88, 169-173 (2000).

56. Glaser, M., Mackay, D. B., Ranicar, A. S. O., Waters, S. L., Brady, F., Luthra, S. K.: Improved targetry and production of ${ }^{124}$ I for PET studies. Radiochim. Acta 92, 951-956 (2004).

57. Sajjad, M., Bars, E., Nabi, H. A.: Optimisation of ${ }^{124} \mathrm{I}$ production via ${ }^{124} \mathrm{Te}(p, n)^{124} \mathrm{I}$ reaction. Appl. Radiat. Isot. 64, 965-970 (2006).

58. Nye, J. A., Avila-Rodriguez, M. A., Nickles, R. J.: Production of $\left[{ }^{124} \mathrm{I}\right]$-iodine on an $11 \mathrm{MeV}$ cyclotron. Radiochim. Acta 94, 213216 (2006).

59. Reischle, G., Rösch, F., Machulla, H.-J.: Electrochemical separation and purification of yttrium-86. Radiochim. Acta 90, 225 (2002).

60. Park, L. S., Szajek, L. P., Wong, K. J., Plascjak, P. S., Garmestani, K., Googins, S., Eckelman, W. C., Carrasquillo, J. A., Paik, C. H.: Semi-automated ${ }^{86} \mathrm{Y}$ purification using a three column system. Nucl. Med. Biol. 31, 297-301 (2004).

61. Kandil, S. A., Scholten, B., Hassan, K. F., Hanafi, H. A., Qaim, S. M.: A comparative study on the separation of radioyttrium from $\mathrm{Sr}$ - and $\mathrm{Rb}$-targets via ion-exchange and solvent extraction techniques, with special reference to the production of no-carrieradded ${ }^{86} \mathrm{Y},{ }^{87} \mathrm{Y}$ and ${ }^{88} \mathrm{Y}$ using a cyclotron. J. Radioanal. Nucl. Chem. 279, 823-832 (2009).
62. Avila-Rodriguez, M. A., Nye, J. A., Nickles, R. J.: Production and separation of non-carrier-added ${ }^{86} \mathrm{Y}$ from enriched ${ }^{86} \mathrm{Sr}$ targets. Appl Radiat. Isot. 66, 9-13 (2008).

63. Tárkányi, F., Kovács, Z., Qaim, S. M., Stöcklin, G.: Production of ${ }^{38} \mathrm{~K}$ via the ${ }^{38} \operatorname{Ar}(p, n)$-process at a small cyclotron. Appl. Radiat. Isot. 43, 503-507 (1992).

64. Merrill, J. C., Lambrecht, R. M., Wolf, A. P.: Cyclotron isotopes and radiopharmaceuticals-XXIV. Titanium-45. Int. J. Appl. Radiat. Isot. 29, 115-116 (1978).

65. Ishiwata, K., Ido, T., Monma, M., Murakami, M., Fukuda, H., Kameyama, M., Yamada, K., Endo, S., Yoshioka, S., Sato, T., Matsuzawa, T.: Potential radiopharmaceuticals labelled with titanium-45. Appl. Radiat. Isot. 42, 707-712 (1991).

66. Klein, A. T. J., Rösch, F., Qaim, S. M.: Investigation of ${ }^{50} \mathrm{Cr}(d, n)$ ${ }^{51} \mathrm{Mn}$ and ${ }^{\text {nat }} \mathrm{Cr}(p, x){ }^{51} \mathrm{Mn}$ processes with respect to the production of the positron emitter ${ }^{51} \mathrm{Mn}$. Radiochim. Acta 88, 253-264 (2000).

67. Klein, A. T. J., Rösch, F., Coenen, H. H., Qaim, S. M.: Production of the positron emitter ${ }^{51} \mathrm{Mn}$ via the ${ }^{50} \mathrm{Cr}(d, n)$ reaction: targetry and separation of no-carrier-added radiomanganese. Radiochim. Acta 90, 167-177 (2002).

68. Reimer, P., Qaim, S. M.: Excitation functions of proton induced reactions on highly enriched ${ }^{58} \mathrm{Ni}$ with special relevance to the production of ${ }^{55} \mathrm{Co}$ and ${ }^{57} \mathrm{Co}$. Radiochim. Acta 80, 113-120 (1998).

69. Sharma, H., Zweit, J., Smith, A. M., Downey, S.: Production of ${ }^{55} \mathrm{Co}$, a short-lived, positron emitting radiolabel for bleomycin. Appl. Radiat. Isot. 37, 105-109 (1986).

70. Zaman, M. R., Qaim, S. M.: Excitation functions of $(d, n)$ and $(d, \alpha)$ reactions on ${ }^{54} \mathrm{Fe}$ : relevance to the production of high purity ${ }^{55} \mathrm{Co}$ at a small cyclotron. Radiochim. Acta 75, 59-63 (1996).

71. Piel, H., Qaim, S. M., Stöcklin, G.: Excitation functions of $(p, x n)$-reactions on ${ }^{\text {nat }} \mathrm{Ni}$ and highly enriched ${ }^{62} \mathrm{Ni}$ : possibility of production of medically important radioisotope ${ }^{62} \mathrm{Cu}$ at a small cyclotron. Radiochim. Acta 57, 1-5 (1992).

72. Rebeles, R. A., van den Winkel, P., Hermanne, A., Tárkányi, F.: New measurement and evaluation of the excitation function of ${ }^{64} \mathrm{Ni}(p, n)$ reaction for the production of ${ }^{64} \mathrm{Cu}$. Nucl. Instrum. Methods B 267, 457-461 (2009).

73. Szelecsényi, F., Boothe, T. E., Tavano, E., Plitnikas, M. E., Tárkányi, F.: Compilation of cross sections/thick target yields for ${ }^{66} \mathrm{Ga}$, ${ }^{67} \mathrm{Ga}$ and ${ }^{68} \mathrm{Ga}$ production using $\mathrm{Zn}$ targets up to $30 \mathrm{MeV}$ proton energy. Appl. Radiat. Isot. 45, 473-500 (1994).

74. Spahn, I., Steyn, G., Nortier, M. F., Coenen, H. H., Qaim, S. M.: Excitation functions of ${ }^{\text {nat }} \mathrm{Ge}(p, x n)^{71,72,73,74} \mathrm{As}$ reactions up to $100 \mathrm{MeV}$ with a focus on the production of ${ }^{72} \mathrm{As}$ for medical and ${ }^{73}$ As for environmental studies. Appl. Radiat. Isot. 65, 1057-1064 (2007).

75. Tárkányi, F., Kovács, Z., Qaim, S. M.: Excitation functions of proton induced nuclear reactions on highly enriched ${ }^{78} \mathrm{Kr}$ : relevance to the production of ${ }^{75} \mathrm{Br}$ and ${ }^{77} \mathrm{Br}$ at a small cyclotron. Appl. Radiat. Isot. 44, 1105-1111 (1993).

76. Scholten, B., Takács, S., Tárkányi, F., Coenen, H. H., Qaim, S. M.: Excitation functions of deuteron induced nuclear reactions on enriched ${ }^{78} \mathrm{Kr}$ with particular relevance to the production of ${ }^{76} \mathrm{Br}$. Radiochim. Acta 92, 203-207 (2004).

77. Qaim, S. M., Stöcklin, G.: Excitation functions of ${ }^{74} \mathrm{Se}(d, x n)$ ${ }^{75,74 \mathrm{~m}} \mathrm{Br}$ reactions: comparative evaluation of possible routes for the production of ${ }^{75} \mathrm{Br}$ at a small cyclotron. Appl. Radiat. Isot. 44, 1443-1447 (1993).

78. Dóczi, R., Takács, S., Tárkányi, F., Scholten, B., Qaim, S. M.: Possibility of production of ${ }^{81} \mathrm{Rb}$ via the ${ }^{80} \mathrm{Kr}(d, n)$ reaction. Radiochim. Acta 88, 135 - 137 (2000).

79. Mustafa, M. G., West Jr., H. I., O’Brien, H., Lanier, R. G., Benhamou, M., Tamura, T.: Measurements and direct-reaction-plusHauser-Feshbach analysis of ${ }^{89} \mathrm{Y}(p, n)^{89} \mathrm{Zr},{ }^{89} \mathrm{Y}(p, 2 n)^{88} \mathrm{Zr}$ and ${ }^{89} \mathrm{Y}(p, p n)^{88} \mathrm{Y}$ reactions up to $40 \mathrm{MeV}$. Phys. Rev. C 38, 16241637 (1988)

80. Busse, S., Rösch, F., Qaim, S. M.: Cross section data for the production of the positron emitting niobium isotope ${ }^{90} \mathrm{Nb}$ via the ${ }^{90} \mathrm{Zr}(p, n)$-reaction. Radiochim. Acta 90, 1-5 (2002).

81. McCarthy, D. W., Bass, L. A., Cutler, P. D., Shefer, R. E., Klinkowstein, R. E., Herrero, P., Lewis, J. S., Cutler, C. S., Anderson, C. J., Welch, M. J.: High purity production and potential applications of copper-60 and copper-61. Nucl. Med. Biol. 26, 351-358 (1999). 
82. Szelecsényi, F., Kovács, Z., Suzuki, K., Okada, K., van der Walt, T. N., Steyn, G. F., Mukherjee, S. J.: Production possibility of ${ }^{64} \mathrm{Cu}$ using proton induced nuclear reactions on zinc for PET studies. J. Radioanal. Nucl. Chem. 263, 539-546 (2005).

83. Thieme, S., Walther, M., Pietsch, H.-J., Steinbach, J.: Copper-61 production and purification. In: Technetium and other Radiometals in Chemistry and Medicine (Mazzi, U., Eckelman, W. C., Volkert, W. A., eds.) 2010 SGE Editoriali, Italy (2010), pp. 475478.

84. Jennewein, M. Qaim, S. M., Hermanne, A., Jahn, M., Tsyganov, E., Slavine, N., Seliounine, S., Antich, P. A., Kulkarni, P. V., Thorpe, P. E., Mason, R. P., Rösch, F.: A new method for radiochemical separation of arsenic from irradiated germanium oxide. Appl. Radiat. Isot. 63, 343-351 (2005).

85. DeJesus, O. T., Nickles, R. J.: Production and purification of ${ }^{89} \mathrm{Zr}$, a potential PET antibody label. Appl. Radiat. Isot. 41, 789-790 (1990).

86. Meijs, W. E., Herscheid, J. D. M., Haisma, H. J., Wijbrandts, R., van Langevelde, F., van Leuffen, P. J., Mooy, R., Pinedo, H. M.: Production of highly pure no-carrier added ${ }^{89} \mathrm{Zr}$ for the labelling of antibodies with a positron emitter. Appl. Radiat. Isot. 45, 11431147 (1994).

87. Holland, J. P., Sheh, Y., Lewis, J. S.: Standardized methods for the production of high specific activity zirconium- 89 . Nucl. Med. Biol. 36, 729-739 (2009).

88. Hohn, A., Coenen, H. H., Qaim, S. M.: Excitation functions of ${ }^{120} \mathrm{Te}(d, x n)^{121,120 \mathrm{~m}, \mathrm{~g}}$ I reactions from threshold up to $13.5 \mathrm{MeV}$ : comparative studies on the production of ${ }^{120 \mathrm{~g}} \mathrm{I}$. Appl. Radiat. Isot. 52, 923-925 (2000).

89. Qaim, S. M.: Production of high purity ${ }^{94 \mathrm{~m}} \mathrm{Tc}$ for positron emission tomography studies. Nucl. Med. Biology 27, 323-328 (2000).

90. Yoo, J., Tang, L., Perkins, T. A., Rowland, D. J., Laforest, R., Lewis, J. S., Welch, M. J.: Preparation of high specific activity ${ }^{86} \mathrm{Y}$ using a small biomedical cyclotron. Nucl. Med. Biol. 32, 891-897 (2005).

91. Lukic, D., Tamburella, C., Buchegger, F., Beyer, G.-J., Comor, J. J., Seimbille, Y.: High efficient production and purification of ${ }^{86} \mathrm{Y}$ based on electrochemical separation. Appl. Radiat. Isot. 67, 523-529 (2009).

92. Sadeghi, M., Zali, A., Avila, M.: A novel method for radiochemical separation of radioyttrium from $\mathrm{Sr}$ targets using precipitation technique. Radiochim. Acta 98, 437-439 (2010).

93. Sahakundu, S. N., Qaim, S. M., Stöcklin, G.: Cyclotron production of short-lived ${ }^{30} \mathrm{P}$. Int. J. Appl. Radiat. Isot. 30, 3-5 (1979).

94. Qaim, S. M., Sutisna, M. S., Ollig, H.: Production of ${ }^{38} \mathrm{~K}$ via the ${ }^{35} \mathrm{Cl}(\alpha, n)$-process at a compact cyclotron. Appl. Radiat. Isot. 39, 479-482 (1988).

95. Nagatsu, K., Kubodera, A., Suzuki, K.: Excitation function measurements of ${ }^{40} \mathrm{Ar}(p, 3 n)^{38} \mathrm{~K},{ }^{40} \mathrm{Ar}(p, 2 p n){ }^{38} \mathrm{Cl}$ and ${ }^{40} \mathrm{Ar}(p, 2 p)^{39} \mathrm{Cl}$ reactions. Appl. Radiat. Isot. 50, 389-396 (1999).

96. Fessler, A., Alfassi, Z. B., Qaim, S. M.: Excitation functions of ${ }^{3} \mathrm{He}$-particle induced nuclear reactions on natural chromium: possibilities of production of ${ }^{52} \mathrm{Fe},{ }^{53} \mathrm{Fe}$ and ${ }^{52} \mathrm{Mn}$ for medical use. Radiochim. Acta 65, 207-213 (1994).

97. Steyn, G. F., Mills, S. J., Nortier, F. M., Simpson, B. R. S., Meyer, B. R.: Production of ${ }^{52} \mathrm{Fe}$ via proton induced reactions on manganese and nickel. Appl. Radiat. Isot. 41, 312-325 (1990).

98. Lagunas-Solar, M. C., Jungerman, J. A.: Cyclotron production of carrier-free cobalt-55, a new positron-emitting label for bleomycin. Int. J. Appl. Radiat. Isot. 30, 25-32 (1979).

99. Szeleczényi, F., Steyn, G. F., Kovács, Z., Vermeulen, C., van der Meulen, N. P., Dolley, S. G., van der Walt, T. N., Suzuki, K., Mukai, K.: Investigation of the ${ }^{66} \mathrm{Zn}(p, 2 p n){ }^{64} \mathrm{Cu}$ and ${ }^{68} \mathrm{Zn}(p, x)$ ${ }^{64} \mathrm{Cu}$ nuclear processes up to $100 \mathrm{MeV}$ : production of ${ }^{64} \mathrm{Cu}$. Nucl. Instrum. Methods B 240, 625-637 (2005).

100. Tárkányi, F., Takács, S., Ditrói, F., Hermanne, A., Sonck, M., Shubin, Yu.: Excitation functions of deuteron induced nuclear reactions on natural zinc up to $50 \mathrm{MeV}$. Nucl. Instrum. Methods B 217, 531-550 (2004).

101. Groppi, F., Bonardi, M. L., Birattari, C., Gini, L., Mainardi, C., Menapace, E., Abbas, K., Holzwarth, U., Stroosnjider, R. M. F.: Thin target excitation functions and optimization of $\mathrm{NCA}{ }^{64} \mathrm{Cu}$ and ${ }^{66,67} \mathrm{Ga}$ production by deuteron induced nuclear reactions on natural zinc target, for radiometabolic therapy and for PET. Nucl. Instrum. Methods B 213, 373-377 (2004).

102. Mushtaq, A., Qaim, S. M., Stöcklin, G.: Production of ${ }^{73} \mathrm{Se}$ via $(p, 3 n)$ and $(d, 4 n)$ reactions on arsenic. Appl. Radiat. Isot. 39, 1085-1091 (1988).

103. Mushtaq, A., Qaim, S. M.: Excitation functions of $\alpha$ - and ${ }^{3} \mathrm{He}-$ particle induced nuclear reactions on natural germanium: Evaluation of production routes for ${ }^{73} \mathrm{Se}$. Radiochim. Acta 50, 27-31 (1990).

104. Faßbender, M., de Villiers, D., Nortier, M., van der Walt, N.: The ${ }^{\text {nat }} \operatorname{Br}(p, x)^{73,75} \mathrm{Se}$ nuclear processes: a convenient route for the production of radioselenium tracers relevant to amino acid labelling. Appl. Radiat. Isot. 54, 905-913 (2001).

105. Alfassi, Z. B., Weinreich, R.: The production of positron emitters ${ }^{75} \mathrm{Br}$ and ${ }^{76} \mathrm{Br}$ : excitation functions and yields for ${ }^{3} \mathrm{He}$ and $\alpha$ particle induced reactions on arsenic. Radiochim. Acta 30, 67-71 (1980).

106. Paans, A. J. M., Welleweerd, J., Vaalburg, W., Reiffers, S., Woldring, M. G.: Excitation functions for the production of bromine75: a potential nuclide for the labelling of radiopharmaceuticals. Int. J. Appl. Radiat. Isot. 31, 267-273 (1980).

107. Kovács, Z., Blessing, G., Qaim, S. M., Stöcklin, G.: Production of ${ }^{75} \mathrm{Br}$ via the ${ }^{76} \mathrm{Se}(p, 2 n)^{75} \mathrm{Br}$ reaction at a compact cyclotron. Int. J. Appl. Radiat. Isot. 36, 635-642 (1985).

108. Spahn, I., Steyn, G. F., Vermeulen, C., Kovács, Z., Szelecsényi, F., Coenen, H. H., Qaim, S. M.: New cross section measurements for production of the positron emitters ${ }^{75} \mathrm{Br}$ and ${ }^{76} \mathrm{Br}$ via intermediate energy proton induced reactions. Radiochim. Acta 97, 535-541 (2009).

109. Youfeng, He, Qaim, S. M., Stöcklin, G.: Excitation functions for ${ }^{3} \mathrm{He}$-particle induced nuclear reactions on ${ }^{76} \mathrm{Se},{ }^{77} \mathrm{Se}$ and ${ }^{\mathrm{nat}} \mathrm{Se}$ : Possibilities of production of ${ }^{77} \mathrm{Kr}$. Int. J. Appl. Radiat. Isot. 33, 13-19 (1982).

110. Diksic, M., Galinier, J. L., Marshall, H., Yaffe, L.: ${ }^{79} \mathrm{Br}$ and ${ }^{81} \mathrm{Br}(p, x n)$ and $(p, p x n)$ excitation functions in the energy range 10-85 MeV. Phys. Rev. C 19, 1753-1761 (1979).

111. Kovács, Z., Tárkányi, F., Qaim, S. M., Stöcklin, G.: Excitation functions for the formation of some radioisotopes of rubidium in proton induced nuclear reactions on ${ }^{\text {nat }} \mathrm{Kr},{ }^{82} \mathrm{Kr}$ and ${ }^{83} \mathrm{Kr}$ with special reference to the production of ${ }^{81} \mathrm{Rb}\left({ }^{81 \mathrm{~m}} \mathrm{Kr}\right)$ generator radionuclide. Appl. Radiat. Isot. 42, 329-335 (1991).

112. Kastleiner, S., Qaim, S. M., Nortier, F. M., Blessing, G., van der Walt, T. N., Coenen, H. H.: Excitation functions of ${ }^{85} \mathrm{Rb}(p, x n)$ ${ }^{85 \mathrm{~m}, 8,83,82,81} \mathrm{Sr}$ reactions up to $100 \mathrm{MeV}$ : integral tests of cross section data, comparison of production routes of ${ }^{83} \mathrm{Sr}$ and thick target yield of ${ }^{82}$ Sr. Appl. Radiat. Isot. 56, 685-695 (2002).

113. Tárkányi, F., Qaim, S. M., Stöcklin, G.: Excitation functions of ${ }^{3} \mathrm{He}$ - and $\alpha$-particle induced nuclear reactions on natural krypton: production of ${ }^{82} \mathrm{Sr}$ at a compact cyclotron. Appl. Radiat. Isot. 39, 135-143 (1988).

114. Sachdev, D. R., Porile, N. T., Yaffe, L.: Reactions of ${ }^{88} \mathrm{Sr}$ with protons of energies 7-85 MeV. Can. J. Chem. 45, 1149-1160 (1967).

115. Kandil, S. A., Spahn, I., Scholten, B., Saleh, Z. A., Saad, S. M. M., Coenen, H. H., Qaim, S. M.: Excitation functions of $(\alpha, x n)$ reactions on ${ }^{\text {nat }} \mathrm{Rb}$ and ${ }^{\text {nat }} \mathrm{Sr}$ from threshold up to $26 \mathrm{MeV}$ : possibility of production of ${ }^{87} \mathrm{Y},{ }^{88} \mathrm{Y}$ and ${ }^{89} \mathrm{Zr}$. Appl. Radiat. Isot. 65, 561568 (2007).

116. Medvedev, D. G., Mausner, L. F., Srivastava, S.: Irradition of strontium chloride targets at proton energies above $35 \mathrm{MeV}$ to produce PET radioisotope ${ }^{86} \mathrm{Y}$. Radiochim. Acta 99, doi: 10.1524/ ract.2011.1880 (2011).

117. Faßbender, M., Novgorodov, A. F., Rösch, F., Qaim, S. M.: Excitation functions of ${ }^{93} \mathrm{Nb}\left({ }^{3} \mathrm{He}, x n\right)^{93 \mathrm{~m}, \mathrm{~g}, 94 \mathrm{~m}, \mathrm{~g}, 95 \mathrm{~m}, \mathrm{~g}} \mathrm{Tc}$ processes from threshold up to $35 \mathrm{MeV}$ : possibility of production of ${ }^{94 \mathrm{~m}} \mathrm{Tc}$ in high radiochemical purity using a thermochromatographic separation technique. Radiochim. Acta 65, 215-221 (1994).

118. Denzler, F.-O., Rösch, F., Qaim, S. M.: Excitation functions of $\alpha$ particle induced nuclear reactions on highly enriched ${ }^{92} \mathrm{Mo}$ : comparative evaluation of production routes for ${ }^{94 \mathrm{~m}} \mathrm{Tc}$. Radiochim. Acta 68, 13-20 (1995); Erratum 75, 227 (1996).

119. Rösch, F., Qaim, S. M., Novgorodov, A. F., Tsai, Y.-M.: Production of positron-emitting ${ }^{110 \mathrm{~m}} \mathrm{In}$ via the ${ }^{110} \mathrm{Cd}\left({ }^{3} \mathrm{He}, 3 n\right){ }^{110} \mathrm{Sn} \rightarrow$ ${ }^{110 \mathrm{~m}}$ In process. Appl. Radiat. Isot. 48, 19-26 (1997). 
120. Tárkányi, F., Szelecsényi, F., Kopecky, P., Molnár, T., Ando, L., Mikecz, P., Toth, G., Rydl, A.: Cross sections of proton induced nuclear reactions on enriched ${ }^{111} \mathrm{Cd}$ and ${ }^{112} \mathrm{Cd}$ for the production of ${ }^{111}$ In for use in nuclear medicine. Appl. Radiat. Isot. 45, 239-249 (1994)

121. Hohn, A., Nortier, F. M., Scholten, B., van der Walt, T. N., Coenen, H. H., Qaim, S. M.: Excitation functions of ${ }^{125} \mathrm{Te}(p, x n)-$ reactions from their respective thresholds up to $100 \mathrm{MeV}$ with special reference to the production of ${ }^{124} \mathrm{I}$. Appl. Radiat. Isot. 55, 149-156 (2001).

122. Uddin, M. S., Hermanne, A., Sudár, S., Aslam, M. N., Scholten, B., Coenen, H. H., Qaim, S. M.: Excitation functions of $\alpha$-particle induced reactions on enriched ${ }^{123} \mathrm{Sb}$ and ${ }^{\text {nat }} \mathrm{Sb}$ for production of ${ }^{124}$ I. Appl. Radiat. Isot. 69, 699-704 (2011).

123. Kastleiner, S., Shubin, Yu. N., Nortier, F. M., van der Walt, T. N., Qaim, S. M.: Experimental studies and nuclear model calculations on $(p, x n)$ and $(p, p x n)$ reactions on ${ }^{85} \mathrm{Rb}$ from their thresholds up to $100 \mathrm{MeV}$. Radiochim. Acta 92, 449-454 (2004).

124. Qaim, S. M., Ollig, H., Blessing, G.: A comparative investigation of nuclear reactions leading to the formation of short-lived ${ }^{30} \mathrm{P}$ and optimization of its production via the ${ }^{27} \mathrm{Al}(\alpha, n)^{30} \mathrm{P}$ process at a compact cyclotron. Int. J. Appl. Radiat. Isot. 33, 271-275 (1982).

125. Blessing, G., Qaim, S. M.: A remotely controlled target and processing system for routine production of ${ }^{38} \mathrm{~K}$ via the ${ }^{35} \mathrm{Cl}(\alpha, n)$ reaction. Appl. Radiat. Isot. 41, 1229-1232 (1990).

126. Tárkányi, F., Qaim, S. M., Stöcklin, G.: Excitation functions of high-energy ${ }^{3} \mathrm{He}$ - and $\alpha$-particle induced nuclear reactions on natural krypton with special reference to the production of ${ }^{82} \mathrm{Sr}$. Appl. Radiat. Isot. 41, 91-95 (1990).

127. Jansen, H. M. L., Pruim, J., v. d. Vliet, A. M., Paans, A. M. J., Hew, J. M., Franssen, E. J. F., de Jong, B. M., Kosterink, J. G. W., Haaxma, R., Korf, J.: Visualisation of damaged brain tissue after ischemic stroke with cobalt-55 positron emitting tomography. J. Nucl. Med. 35, 456-460 (1994).

128. Boothe, T. E., Tavano, E., Munoz, J., Carroll, S.: Coproduction of ${ }^{64} \mathrm{Cu}$ and ${ }^{67} \mathrm{Cu}$ with ${ }^{67} \mathrm{Ga}$ using protons on ${ }^{68} \mathrm{Zn}$. J. Label. Compd. Radiopharm. 30, 108 (1991).

129. Smith, S. V., Waters, D. J., Di Bartolo, N.: Separation of ${ }^{64} \mathrm{Cu}$ from ${ }^{67} \mathrm{Ga}$ waste products using anion exchange and low acid aqueous/organic mixtures. Radiochim. Acta 75, 65-68 (1996).

130. Kandil, S. A., Scholten, B., Hassan, K. F., Hanafi, H. A., Qaim, S. M.: A comparative study on the separation of radioyttrium from $\mathrm{Sr}$ - and $\mathrm{Rb}$-targets via ion-exchange and solvent extraction techniques, with special reference to the production of no-carrieradded ${ }^{86} \mathrm{Y},{ }^{87} \mathrm{Y}$ and ${ }^{88} \mathrm{Y}$ using a cyclotron. J. Radioanal. Nucl. Chem. 279, 823-832 (2009).

131. Qaim, S. M.: Cyclotron production of generator radionuclides. Radiochim. Acta 41, 111-117 (1987).

132. Rösch, F., Knapp, F. F.: Radionuclide generators. In: Handbook of Nuclear Chemistry. Vol. 4 (Rösch, F., ed.) Kluwer, Dordrecht, The Netherlands (2003), pp. 81-118.

133. Tárkányi, F., Takács, S., Gul, K., Hermanne, A., Mustafa, M. G., Nortier, F. M., Oblozinsky, P., Qaim, S. M., Shubin, Yu. N., Youxiang, Z.: Beam monitor reactions. In: Charged Particle CrossSection Database for Medical Radioisotope Production: Diagnostic Radioisotopes and Monitor Reactions. IAEA-TECDOC-1211, Vienna, Austria (2001), pp. 49-152.

134. Szelecsényi, F., Kovács, Z., van der Walt, T. N., Steyn, G. F., Suzuki, K., Okada, K.: Investigation of the nat $\mathrm{Zn}(p, x)^{62} \mathrm{Zn}$ nuclear process up to $70 \mathrm{MeV}$ : a new ${ }^{62} \mathrm{Zn} /{ }^{62} \mathrm{Cu}$ generator. Appl. Radiat. Isot. 58, 377-384 (2003).

135. Mathis, C. A., Lagunas-Solar, M. C., Sargent III, T., Yano, Y., Vuletich, A., Harris, L. J.: A ${ }^{122} \mathrm{Xe}^{-122} \mathrm{I}$ generator for remote radioiodinations. Appl. Radiat. Isot. 37, 258-260 (1986).

136. Tárkányi, F., Qaim, S. M., Stöcklin, G., Sajjad, M., Lambrecht, R. M.: Nuclear reaction cross sections relevant to the production of the ${ }^{122} \mathrm{Xe} \rightarrow{ }^{122} \mathrm{I}$ generator system using highly enriched ${ }^{124} \mathrm{Xe}$ and a medium-sized cyclotron. Appl. Radiat. Isot. 42, 229-233 (1991).

137. Jennewein, M., Schmidt, A., Novgorodov, A. F., Qaim, S. M., Rösch, F.: A no-carrier-added ${ }^{72} \mathrm{Se} /{ }^{72} \mathrm{As}$ radionuclide generator based on distillation. Radiochim. Acta 92, 245-249 (2004).

138. Jennewein, M., Qaim, S. M., Kulkarni, P. V., Mason, R. P., Hermanne, A., Rösch, F.: A no-carrier-added ${ }^{72} \mathrm{Se} /{ }^{72} \mathrm{As}$ radionuclide generator based on solid phase extraction. Radiochim. Acta 93, 579-583 (2005).

139. Hilgers, K., Shubin, Yu.N., Coenen, H. H., Qaim, S. M.: Experimental measurements and nuclear model calculations on the excitation functions of ${ }^{\text {nat }} \mathrm{Ce}\left({ }^{3} \mathrm{He}, x n\right)$ and ${ }^{141} \mathrm{Pr}(p, x n)$ reactions with special reference to production of the therapeutic radionuclide ${ }^{140} \mathrm{Nd}$. Radiochim. Acta 93, 553-560 (2005).

140. Zhernosekov, K. P., Filosofov, D. V., Qaim, S. M., Rösch, F.: $\mathrm{A}{ }^{140} \mathrm{Nd} /{ }^{140} \mathrm{Pr}$ radionuclide generator based on physico-chemical transitions in ${ }^{140} \mathrm{Pr}$ complexes after electron capture decay of ${ }^{140}$ Nd-DOTA. Radiochim. Acta 95, 319-327 (2007).

141. Daraban, L., Rebeles, R. A., Hermanne, A., Tárkányi, F., Takács, S.: Study of the excitation functions for ${ }^{43} \mathrm{~K},{ }^{43,44,44 \mathrm{~m}} \mathrm{Sc}$ and ${ }^{44} \mathrm{Ti}$ by proton irradiations of ${ }^{45} \mathrm{Sc}$ up to $37 \mathrm{MeV}$. Nucl. Instrum. Methods B 267, 755-759 (2009).

142. Qaim, S. M., Tárkányi, F., Takács, S., Hermanne, A., Nortier, M., Oblozinsky, P., Scholten, B., Shubin, Yu.N., Youxiang, Z.: Positron emitters. In: Charged Particle Cross-Section Database for Medical Radioisotope Production: Diagnostic Radioisotopes and Monitor Reactions. IAEA-TECDOC-1211, Vienna, Austria (2001), pp. 234-280.

143. Filosofov, D. V., Loktionova, N. S., Rösch, F.: A ${ }^{44} \mathrm{Ti} /{ }^{44} \mathrm{Sc}$ radionuclide generator for potential application of ${ }^{44} \mathrm{Sc}$-based PETradiopharmaceuticals. Radiochim. Acta 98, 149-156 (2010).

144. Pruszynski, M., Loktionova, N. S., Filosofov, D. V., Rösch, F.: Post-elution processing of ${ }^{44} \mathrm{Ti} /{ }^{44} \mathrm{Sc}$ generator-derived ${ }^{44} \mathrm{Sc}$ for chemical application. Appl. Radiat. Isot. 68, 1636-1641 (2010).

145. Nickles, R. J., Nunn, A. D., Stone, C. K., Christian, B. T.: Technetium-94m-terboroxine: synthesis, dosimetry and initial PET imaging studies. J. Nucl. Med. 34, 1058-1066 (1993).

146. Szajek, L., Kung, H., Plascjak, P., Klössl, K., Acton, P. C., Herscovitch, P., Eckelman, W. C.: Comparison of [ $\left.{ }^{94 \mathrm{~m}} \mathrm{Tc}\right]-$ and $\left[{ }^{99 \mathrm{~m}} \mathrm{Tc}\right]-$ trodat-1 as imaging agents for the dopamine transporter. J. Label. Compd. Radiopharm. 42, 545-547 (1999).

147. Herzog, H., Rösch, F., Stöcklin, G., Lueders, C., Qaim, S. M., Feinendegen, L. E.: Pharmacokinetics of ${ }^{86} \mathrm{Y}$-citrate in a patient with multiple bone metastases measured with PET and calculation of radiation dose in ${ }^{90} \mathrm{Y}$-citrate radiotherapy. J. Nucl. Med. 34, 2222-2226 (1993).

148. Philpott, G. W., Schwarz, S. W., Anderson, C. J., Dehdashti, F., Connett, J. M., Zinn, K. R., Meares, C. F., Cutler, P. D., Welch, M. J., Siegel, B. A.: Radioimmuno PET: detection of colorectal carcinoma with positron-emitting copper-64-labelled monoclonal antibody. J. Nucl. Med. 36, 1818-1824 (1995). 